\title{
La experiencia de Semilleros de investigación en Filosofía latinoamericana como espacio de reconocimiento de la realidad de los y las participantes de los grados décimo y once del Colegio CODEMA IED
}

Trabajo de Grado

\author{
Oswaldo González Abril \\ Código: 2177705 \\ Tutor: Claudia Patricia Giraldo \\ Facultad de Filosofía y Letras \\ Maestría en Filosofía Latinoamericana \\ Universidad Santo Tomás
}

Bogotá. Mayo 2017 


\section{Resumen}

El presente trabajo de investigación pretende responder y aportar información a la comunidad académica en relación a la siguiente pregunta: ¿en qué medida el semillero de investigación en Filosofía Latinoamericana permite a los y las estudiantes de los grados décimo y once del colegio CODEMA IED, el reconocimiento de su realidad y la configuración de un pensamiento crítico a través de la sistematización de experiencias y de la construcción colectiva de conocimiento? Para ello retomamos principalmente los aportes teóricos que ofrece Orlando Fals Borda en su abordaje del estudio de la realidad como fuente de transformación de la misma, además de los aportes dados por la Investigación Acción Participativa y algunos de sus exponentes.

El planteamiento de una propuesta pedagógica que nos brinda los elementos necesarios para la construcción de conocimiento a partir del estudio de la realidad de los y las jóvenes participantes del semillero Intus Legere y sus prácticas investigativas, orientadas al análisis y sistematización de la transformación de la realidad de los y las participantes del semillero con base en la comprensión y descripción de sus encuentros, permitieron dar respuesta al problema de investigación. Una práctica pedagógica que conduzca a la construcción colectiva de conocimiento, que estructure espacios y escenarios de resistencia que permita la participación continua y de valor a ese saber popular, a ese sentido común, a esa filosofía espontanea, se consolidará como una práctica reflexiva, transformadora de las realidades de quienes hacen parte de ella.

Palabras clave: realidad, filosofía latinoamericana, semillero, IAP, educación. 


\section{Dedicatoria}

Dedico esta investigación con todo mi amor a mi esposa Zaida por haberme apoyado incondicionalmente. A mi hija Manuela por regalarme de su tiempo para poder llevar a cabo esta investigación. Y A mis padres Carlos y Laura quienes forjaron en mi un sentimiento de continua superación. 


\section{Agradecimientos}

Expreso mis más sentidos agradecimientos a los y las estudiantes del Colegio CODEMA IED, quienes día a día forjaron procesos de reflexión continua que me impulsaron a buscar una transformación en mí que hacer como maestro.

A la Universidad Santo Tomás y a sus maestros por permitirme construir opciones distintas para mis estudiantes.

A mi familia por su constante apoyo y motivación.

A mi tutora Claudia Giraldo por toda su comprensión y dedicación. 


\section{Contenido}

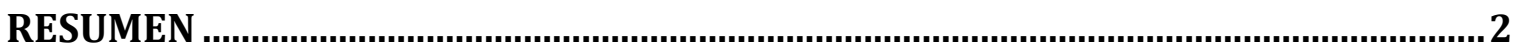

DEDICATORIA.............................................................................................................. 3

INTRODUCCIÓN .......................................................................................................... 7

EN BUSCA DE UN CONOCIMIENTO ALTERNO............................................................ 9

Antecedentes y el problema de investigación ........................................................................................ 9

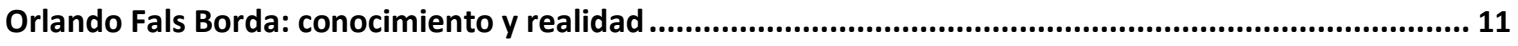

El conocimiento alterno: praxis, realidad y transformación de la realidad............................................... 19

Investigación acción participativa................................................................................................. 22

Papel de la educación en la transformación de la realidad................................................................. 26

Aportes de los teóricos de la Investigación acción................................................................................... 29

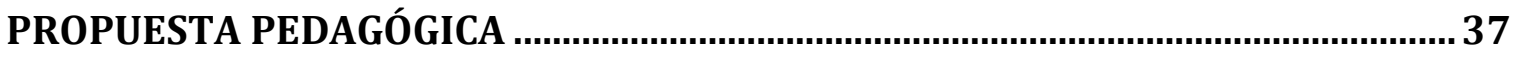

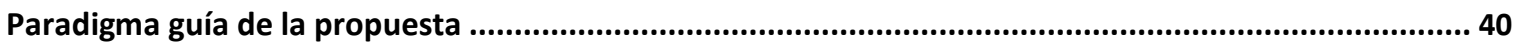

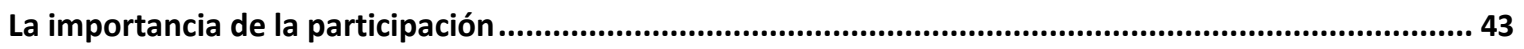

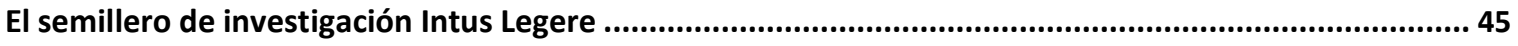

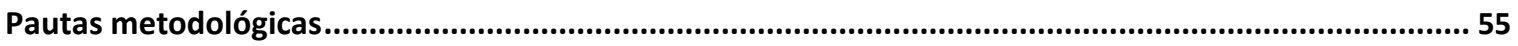

DESARROLLO METODOLÓGICO DE LA PROPUESTA Y SISTEMATIZACIÓN .......... 56

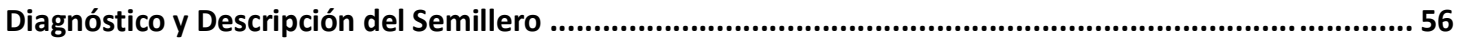


Descripción de los encuentros

Análisis y Evaluación de la propuesta

Sistematización

Hacia un análisis de los relatos.

Los participantes y sus características

Representatividad.

Metodología.

Análisis de mi práctica pedagógica

APÉNDICE 1

APÉNDICE 2

APÉNDICE 3 


\section{Introducción}

El presente trabajo de investigación se plantea como objetivo fundamental responder y aportar información a la comunidad educativa en relación a la siguiente pregunta de investigación: ¿en qué medida el semillero de investigación en Filosofía Latinoamericana permite a los y las participantes de los grados décimo y once del colegio CODEMA IED, el reconocimiento de su realidad y la configuración de un pensamiento crítico a través de la sistematización de experiencias y de la construcción colectiva de conocimiento? La pregunta de investigación planteada busca la relación entre los siguientes aspectos: 1) El semillero de investigación y su incidencia en la observación, comprensión y reconocimiento de la realidad de los y las jóvenes participantes, 2) El semillero de investigación y la producción de conocimiento, 3) El semillero de investigación y la construcción de pensamiento crítico.

Planteo entonces como propuesta que a partir del semillero de investigación en filosofía latinoamericana se valide como un escenario en el que tanto el profesional en educación como sus estudiantes desde sus propias necesidades y realidades busquen la mejora de sus condiciones de vida, desde la observación y vivencia misma, es decir desde la práctica se teorice.

En la historia de América Latina se encuentran innumerables textos, ideas y personajes que han abogado por la necesidad de conocer la realidad y la historia propia. Las justificaciones y formas para lograrlo son innumerables. Para esta investigación se ha seleccionado la propuesta de Orlando Fals Borda por sus valiosos aportes en el estudio de la realidad y su transformación desde las colectividades mismas.

El desarrollo de la investigación aborda tres momentos de reflexión: El primero, propone presentar y analizar el problema de investigación, así como construir el soporte teórico que guio el proceso de creación y evaluación del semillero de investigación Intus Legere; a partir de la búsqueda de respuestas a las preguntas ¿por qué es importante que la educación y la producción de conocimiento logren un conocimiento de la realidad "local" y una transformación de la misma? ¿Qué tienen que ver estos procesos con la formación de un pensamiento crítico? en el pensamiento de Fals Borda y de algunos representantes de la IA. 
El segundo momento se refiere a la propuesta pedagógica que nos brinda los elementos necesarios para la construcción de conocimiento a partir del estudio de la realidad de los y las jóvenes participantes del semillero Intus Legere con miras al logro de su transformación y a la generación de un pensamiento crítico, mi planteamiento es que una vía pedagógica idónea es la creación de un semillero de investigación y la sistematización del mismo. La propuesta parte del principio de la búsqueda por el reconocimiento de los saberes y disposiciones previos, de los sistemas de creencias que todos tenemos, de esta manera que se pueda generar una real curiosidad epistémica en los jóvenes del Colegio CODEMA IED. Para lo cual me apoyo en la propuesta de Fals Borda, quien afirma que un conocer a partir de la práctica es una actividad transformadora que está arraigada en las necesidades concretas de los sujetos.

Para finalizar un tercer momento que fundamenta las prácticas investigativas, orientadas al análisis y sistematización de la transformación de la realidad de los y las participantes del semillero con base en la comprensión y descripción de sus encuentros y la sistematización de los relatos como producto del trabajo realizado al interior del semillero.

El semillero de investigación tiene como finalidad el reconocimiento de las realidades de los y las jóvenes de los grados $10^{\circ}$ y $11^{\circ}$ del colegio CODEMA IED por parte de ellos y de sus maestros como vía para que los procesos de construcción y asimilación de conocimientos surjan del contacto con la vida real, con las circunstancias y con el medio que les rodea permitiendo que sus descubrimientos e iniciativas sean útiles para su contexto y su comunidad y permitan tener actitudes reflexivas y críticas frente a diferentes procesos a los que nos avocan los diferentes sistemas mundiales económicos y políticos.

Como estudiante de la Maestría en Filosofía Latinoamericana la presente investigación me permitió el abordaje de nuevas maneras de aproximación a la realidad y a la transformación de la misma, consolidó procesos de construcción de conocimiento desde la colectividad y afianzó las bases de una filosofía práctica y más cercana al contexto educativo en el que me desenvuelvo. Por otro lado me generó procesos de reflexión frente a la manera como venía abordando la filosofía en mi practica pedagógica y amplio el horizonte para el estudio de la filosofía latinoamericana con miras a largo plazo en la consolidación de una identidad propia y colectiva. 


\section{Capítulo 1}

\section{En busca de un Conocimiento alterno}

El presente capítulo pretende presentar y analizar el problema de investigación, así como construir el soporte teórico que guio el proceso de creación y evaluación del semillero de investigación Intus Legere. En la primera parte de este capítulo presento la situación que produjo la pregunta de investigación. En los siguientes apartados busqué las respuestas a las preguntas ¿por qué es importante que la educación y la producción de conocimiento logren un conocimiento de la realidad "local” y una transformación de la misma? ¿Qué tienen que ver estos procesos con la formación de un pensamiento crítico? en el pensamiento de Fals Borda y de algunos representantes de la IA.

\section{Antecedentes y el problema de investigación}

Cuando inicié como maestro de filosofía consideraba que un joven no podía graduarse sin conocer a Platón o a Aristóteles, no a profundidad pues en la escuela no se llega ni siquiera a eso; me empecinaba en hacer clases magistrales sobre Nietzsche, Sartre, Kant, entre otros y sentirme orgulloso cuando en las evaluaciones los estudiantes repetían con precisión su biografía y obras. No comprendía cómo estos jóvenes mostraban tanto desdén. No hallaba las razones por las cuales no vibraban ante las formas de ver el mundo de estos filósofos.

Hoy día, por más que acudo a la didáctica encuentro a estos jóvenes sumidos en un mundo consumista; observo a diario como se deslumbran fácilmente con el celular de última tecnología y escucharlos decir: "que no importa lo que tengan que hacer" para conseguirlo así eso implique dejar de tomar onces, un transporte y hacer muchas otras cosas más. Son jóvenes que están acostumbrados a dar mayor valor a las cosas que se poseen pues son estas las que los sitúan y posicionan ante los demás, sin embargo, no se puede desconocer que cuentan con un potencial critico ante su realidad. La carencia del dinero debido a sus condiciones familiares los hace vulnerables a los medios de comunicación quienes les venden "realidades" fundadas en un mercado globalizante. De ahí que para ellos los datos, las biografías o las obras de los protagonistas de la 
filosofía pierden vigencia ya que esa información la encuentran inservible en su realidad y poco cercana a sus intereses. Todo esto me ha llevado a sentir que me estoy volviendo obsoleto.

Como maestros buscamos en la didáctica las estrategias que nos permitan que jóvenes como estos, se motiven, sientan ese deseo por aprender; rediseñamos nuestras planeaciones año tras año, los llevamos a foros, buscamos en la tecnología un aliado para hacer más dinámicas nuestras clases. No obstante, encontramos que ellos solo esperan cumplir con unos mínimos (notas) que los lleven al otro curso, poder graduarse y así "hacer lo que quieren". La presión de pasar una materia, o un grado sobrepasa el propio interés. Enamorarlos de la filosofía, se ha convertido en un objetivo propio de mi accionar como maestro, que encuentren en ella la posibilidad de reconocerse como son, de reconocer su realidad e intentar cambiarla. Para ello es claro que no se puede seguir sujeto a una nota, al hecho de pasar una materia o un curso, debe ser por iniciativa propia. Hallar la manera para que su deseo de conocimiento sea motivado desde sí mismo, es decir sea intrínseco y no sujeto a motivaciones externas, que se fundamente en la capacidad de asombro con la que todos nacemos pero que por diversas razones perdemos con el tiempo.

Los y las jóvenes del Colegio CODEMA IED, usualmente expresan cuando deben "aprender" algo, que eso para qué les sirve en la vida, que ellos no le ven razón de ser, pero urgidos por pasar una materia o el mismo grado caen en esa dicotomía de repetir y repetir para que otros crean que si han aprendido. Como maestro en Filosofía puedo dar cuenta, como lo comenté anteriormente, que incluso muchas de las preguntas que se hacen a diario los y las estudiantes en la clase, no son valoradas, por creerlas utópicas, o ilusas; por el afán que me imprime un plan de asignatura que me obliga a que vean determinadas temáticas. Temáticas que han sido trazadas por un programa externo que solo da valor a lo realizado por hombres de otros contextos y que no deja espacio para que esa "filosofía espontánea", ese "saber popular" se pueda promover. En este trabajo intento responder a esta situación a través de la implementación y sistematización de una experiencia pedagógica alternativa a mis clases regulares de filosofía.

A este planteamiento subyacen varios aspectos a considerar: el primero en relación con si ese saber popular que surge de las interacciones con los y las jóvenes, si esa "filosofía espontánea" que es diaria en las aulas, ese conocimiento práctico producto de mi ejercicio como docente se puede considerar como válido dentro de un proceso de investigación y si a partir de la 
sistematización de esa experiencia se puede llegar a un reconocimiento y transformación de la realidad de los actores participantes, docente y alumnos.

Esta situación latente y persistente año tras año me llevó a encontrar autores como Orlando Fals Borda, que aunque todo su trabajo en torno a la investigación de la realidad para transformarla empezó desde los años cincuenta, sigue y continua vigente en escenarios en los que queremos comprender nuestra realidad e intentar su transformación. Por ello retomaremos sus aportes en torno al reconocimiento y valor a la realidad como fuente de investigación y transformación.

\section{Orlando Fals Borda: conocimiento y realidad}

Encuentro cómo la filosofía y la sociología han respondido a estos interrogantes, por ello para discernir las respuestas me guiaré por las reflexiones planteadas por Orlando Fals Borda (1925-2008) en lo referente a sus planteamientos sociológicos sobre educación, ciencia y realidad. Este autor fue un destacado sociólogo y educador, pensador crítico más reconocido en Colombia y en América Latina; su vida la consagró a la reflexión y a la crítica de las condiciones de la población colombiana, sus estudios en relación con las maneras de accionar de las comunidades fueron grandes aportes a la sociología y en particular a la investigación transformadora especialmente por sus ideas metodológicas sobre la Investigación Acción Participación. Eminente sociólogo que tuvo una influencia decisiva en las ideas políticas, sociológicas y educativas en Latinoamérica en la segunda mitad del siglo XX con proyecciones hacia el siglo XXI.

El presente documento se apoya en los capítulos "La crisis, el compromiso y la ciencia", "Experiencias teórico prácticas" y "Por la Praxis: el problema de cómo investigar la realidad para transformarla de la obra "Antología: Una Sociología sentipensante para América Latina” dirigida por Víctor Manuel Moncayo; y en los capítulos El Neohumanismo en la Sociología contemporánea, situación contemporánea de la IAP y vertientes afines, Universidad y sociedad, y la superación del eurocentrismo, Manifiesto por la ciencia, de su libro Socialismo raizal y el ordenamiento territorial. Además, tuve como aportes lo descrito en su artículo La ciencia y el pueblo: nuevas reflexiones. Así como el artículo de Javier Ocampo López: El maestro Orlando Fals Borda, sus ideas educativas y sociales para el cambio en la sociedad colombiana. Así como en autores como Javier Calderón y Diana López Cardona, Álvaro Camacho, Damián Pachón Soto, 
quienes desde sus análisis que hacen del trabajo de Orlando Fals Borda también contribuyeron teóricamente al desarrollo de la presente investigación.

Intentaré desde los aportes de Orlando Fals Borda dar respuestas a los interrogantes teóricos planteados para el desarrollo de la presente investigación: ¿por qué es importante que la educación y la producción de conocimiento científico estén enfocadas en el reconocimiento de la realidad "local” y una transformación de la misma?, ¿cuál es la relación entre saberes producidos los sociales, comunitarios o populares, incluidos los producidos en el aula, y la ciencia? , ¿Sí son válidos estos saberes? ¿cuál es la relación entre la producción de conocimiento, el orden mundial y las identidades locales? ¿Qué tienen que ver estos procesos con la formación de un pensamiento crítico? Establecí como punto de partida la idea de conocimiento que se plantea el autor y de esta manera llegar al concepto de realidad y al papel de la educación en ese reconocimiento, así como identificar por qué ese reconocimiento puede propiciar espacios de reflexión y formación de un pensamiento crítico, y que es lo que ayudaría a hacerlo.

En primera instancia analizaremos lo planteado por el autor en lo que respecta al conocimiento. Fals Borda afirma que:

Se debe también superar aquella confusión de equiparar el significado del vocablo conocimiento con el del vocablo información. Por el primero se debería entender el enunciado de interpretaciones abstractas explicativas de los factores o causas implicadas en la ocurrencia de un determinado fenómeno natural o social. Interpretaciones a la vez interrelacionables y conformantes de un cuerpo de explicaciones total, dotado de la capacidad de generar predicciones, sometibles a la prueba de la observación o experimentación. En síntesis se trataría de obtener que el conocimiento resulte de la confrontación dialéctica de tales cuerpos de explicaciones o "saberes" conformadores de las líneas de pensamiento con la realidad local, regional o universal. Los conocimientos así obtenidos, pueden formularse en forma de teorías, modelos o enunciados (Fals, 2013, p. 206).

Para el autor es fundamental tener claridad en la diferencia existente entre información y conocimiento, ya que: 
Deberán tenerse en cuenta en el establecimiento de criterios para la evaluación del rendimiento y nivel de calidad académica, científica o tecnológica en nuestras instituciones educativas, en sustitución de aquellos criterios que apuntan a medir la simple capacidad de retener, en la memoria, así sea pasajeramente, la información sobre los temas o asuntos expuestos en las cátedras o en los textos de estudio y consulta. Sobra destacar la importancia que esto tendría en la formación en nuestros países de nuevas promociones de científicos, así como en los procesos de creación de los conocimientos indispensables para señalar el camino apropiado que conduzca a nuestra sociedad hacia el desarrollo sustentable endógeno (Fals, 2013, p. 207).

Un desarrollo sustentable endógeno requiere que la producción de conocimiento se genere desde las mismas realidades locales o regionales para dar respuesta a sus propias necesidades para ello el autor plantea que «esto se puede hacer dentro del marco de una concepción holística y sistémica que advierta sobre la inconveniencia de generalizar los conocimientos de un fragmento de la realidad a toda ella» (Fals, 2013, p. 204). Por lo tanto, para Fals Borda el conocimiento científico es aquel que suma y que confronta saberes. Se puede producir conocimiento usando el conocimiento científico generado en diferentes latitudes sumado al conocimiento producido desde la realidad local. Atendiendo a ese conjunto de "saberes" o explicaciones que confrontadas dialécticamente y en relación con las líneas de pensamiento generarían un conocimiento desde, por y para sus propios contextos. Atendiendo a este concepto de conocimiento el autor también da validez a esa producción de conocimiento que se gesta desde la práctica misma, desde esa sabiduría popular originada desde la realidad local, regional y universal para dar respuesta a las necesidades propias de esos contextos.

En el Tercer Congreso Nacional de Sociología en el año de 1981 se definió el "saber o sabiduría popular":

Como el conocimiento empírico, práctico, de sentido común, que ha sido posesión cultural e ideológica ancestral de las gentes de las bases sociales, aquel que les ha permitido crear, trabajar e interpretar predominantemente con los recursos directos que la naturaleza ofrece al hombre. Este saber popular no está modificado a la usanza dominante, y por eso se desprecia y relega como si no tuviera el derecho de articularse y expresarse en sus propios términos. Pero el saber popular o folclórico tiene también su 
racionalidad y su propia estructura de causalidad, es decir puede demostrarse que tiene mérito y validez científica en sí mismo (Fals, 1981, p. 182).

Para el autor el saber popular o folclórico tiene su propia racionalidad y su propia estructura de causalidad, es decir puede demostrarse que tiene mérito y validez científica en sí mismo: «Al recibir y considerar sin prejuicios la sabiduría popular y el sentido común, el conocimiento académico interdisciplinario puede propiciar críticamente una comprensión holística o más completa de la realidad, y así enriquecer y simplificar formas y estilos de la comunicación con las comunidades estudiada» (Fals, 1978, p. 331).

Concebir el conocimiento como el resultado de la confrontación dialéctica entre esos "saberes" o explicaciones logra responder a las realidades y a las necesidades locales, regionales, o universales, como dice Fals Borda se trata de nivelar los paradigmas, de darle el mismo valor y de fortalecer y crear paradigmas endógenos.

Si un marco científico de referencia no se arraiga en el medio donde se quiere aplicar, es comprensible que aparezcan rezagos y desfases teóricos - prácticos, con implicaciones disfuncionales para los sistemas culturales, sociales, políticos y económicos. (Fals, 2013, p.202).

Así como el autor destaca que los conocimientos son constructos culturales generados en lugares geográficos específicos también destaca que la producción de conocimiento va ligada a los intereses y objetivos de las clases dominantes y por ende del proceso histórico en el que se encuentran:

La ciencia no es sino un producto cultural del intelecto humano, producto que responde a necesidades colectivas concretas - incluidas las consideradas artísticas, sobrenaturales y extra científicas- y también a objetivos determinados por clases sociales que aparecen dominantes en ciertos periodos históricos (Fals, 1981, p. 180).

Al afirmar que la ciencia se construye a partir de un tipo de racionalidad y en una cultura determinada y que está regida por intereses particulares, lo que nos está diciendo el autor es que la ciencia es situada y corresponde al proceso histórico en el que se encuentran quienes la producen. «No puede haber valor absoluto en el conocimiento científico, ya que su valor variará según los 
intereses objetivos de las clases envueltas en la formación y acumulación del conocimiento, esto es, en su producción» (Fals, 1981, p. 180), Sin embargo y por ello mismo:

Debemos seguir examinando fríamente e impulsando la ciencia emergente y reprimida y la cultura subversiva, y trabajar por un reordenamiento del quehacer científico que sea útil y conveniente, que tenga en cuenta las necesidades de las mayorías, víctimas del avance que ha traído el "progreso" desequilibrado de la misma ciencia (Camacho, 1986, p. 214).

Para el autor, aunque la producción de conocimiento se encuentra ligada a la coyuntura histórica, al ordenamiento social imperante y por ende responde a los intereses de quien domina; su aparato científico se encuentra construido para defender dichos intereses; contiene en sí misma una dimensión ideológica y política significativa. Es posible generar e impulsar una ciencia emergente o endógena que tenga en cuenta las necesidades de las mayorías excluidas. Ahora bien «si el proceso de proceso de producción del conocimiento va ligado como viene dicho a una base social, es necesario descubrir esta base para entender los vínculos que existen entre el desarrollo del pensamiento científico, el contexto cultural y la estructura de poder de la sociedad» (Fals, 1981, p. 183). Sin embargo y como lo afirma Fals Borda no se trata de aislarnos o descartar el conocimiento obtenido en otras épocas o de otros escenarios geográficos, o de otras corrientes intelectuales puesto que esto nos conduciría a un atraso rotundo, como se mencionó se trata de sumar y de contrastar los diferentes tipos de conocimiento dialécticamente. Lograr esta confrontación no es fácil pues lo que ha venido pasando es una transferencia de conocimientos venidos de otros contextos.

Encontramos en lo enunciado por Fals Borda en su apartado ciencia y realidad, las implicaciones negativas que produjo en su momento el que no hubiese una correspondencia entre la realidad local y la transferencia de conocimiento de otros contextos, y las alternativas de solución. Específicamente para el caso de la sociología el autor menciona las dificultades en el trabajo de campo realizado con obreros, campesinos e indígenas colombianos en el año de 1970, debido a que los marcos teóricos y metodológicos eran inaplicables a la realidad que se pretendía estudiar. 
En primera instancia menciona la causalidad. El paradigma positivista creía que su concepto de causalidad se aplicaba igual en las ciencias naturales y en las ciencias sociales. Fals Borda empleando técnicas propias encontró que en el estudio de los movimientos sociales este paradigma se resquebrajaba ya que «la materia prima que se manejaba pertenece a una categoría ontológica distinta, que tiene cualidades propias» (Fals, 1978, p.259 ). Los fenómenos sociales son multidimensionales y para su comprensión el concepto de multicausalidad es fundamental. Adquiriendo una dimensión teórico- práctica supeditada al criterio de las opciones de acción, del sentido de estas acciones y atendiendo a que esta última es de carácter volitivo y no se encuentra determinada en un sentido único sino múltiple.

Otra de las implicaciones analizadas por el autor corresponde a lo que llama la constatación del conocimiento, el cual para el autor tiene que ver con la llamada observación experimental. Si bien en las ciencias sociales se tenía claridad que el observador formaba parte del universo observado, se le exigía de acuerdo a lo establecido por el paradigma positivista una objetividad y neutralidad, generando unas claras diferencias entre el observador y lo observado haciendo que las comunidades estudiadas fuesen víctimas de una explotación científica. De ahí surgió la necesidad de que el investigador tuviese una plena identificación con los grupos o comunidades que investigaba. Esta inserción llevó al reconocimiento más profundo del saber popular y a la búsqueda de factores que pudieran articularlo con el conocimiento científico.

En este ejercicio sociológico dieron cuenta también de que «la práctica permitió constatar que el investigador puede ser sujeto y objeto de su propia investigación» Se dio paso a la participación activa del investigador, el cual busca ajustar las herramientas que aun cuando son propias de la corriente positivista, pueden ser de bastante ayuda si se perfeccionan y contribuyen a las necesidades de las comunidades estudiadas.

La tercera limitante mencionada por el autor es la idea de realidad objetiva. La corriente positivista pretendía en su estudio de la realidad hacer "cortes seccionales" en los que «la realidad objetiva aparecía como "cosas en si” que se movían en la dimensión espacio tiempo y que venían de un pasado histórico condicionante» (Fals, 1978, p. 265). El autor recuerda cómo se fue haciendo cada vez más notable la necesidad de convertir esas cosas en sí en cosas para nosotros. 
Otra dificultad que señala el autor es que el trabajo realizado con las comunidades arrojó que los investigadores estaban permeados por la influencia del positivismo, y esperaban encontrar en el terreno leyes, marcos de referencia conceptuales propias de otros escenarios lo que hizo que se adoptaran interpretaciones que no correspondían a las realidades observadas. Concluye Fals Borda que esto produjo interpretaciones incompletas y un conocimiento que no ayudaba a una acción política eficaz.

(...) hubo de buscarse soluciones teóricas alternas que permitieran una mayor aproximación a la realidad para entenderla y transformarla para ello se empleó el método dialéctico aplicado en pasos alternos y complementarios: a) propiciando un intercambio entre conceptos conocidos, o preconceptos, y los hechos (o sus percepciones)con observaciones adecuadas en el medio social; b)siguiendo con la acción a nivel de base para constatar en la realidad del medio lo que se quería conceptualizar; c)retornando a reflexionar sobre ese conjunto experimental para deducir conceptos más adecuados y obtener mejores luces sobre viejos conceptos o teorías que así se adaptaron al contexto real; y d) volviendo a comenzar el ciclo de investigación para culminarlo en la acción (Fals, 1978, p.278).

La incidencia y limitaciones del paradigma positivista que Fals Borda denunció en los años setentas permeó la manera como se investigaba la realidad, pese a los cambios y transformaciones de este paradigma, la ciencia social producida en Europa sigue permeando la producción del conocimiento en América latina, lo que el autor define como colonialismo intelectual. Esta imposición ha permitido que los estudios sobre nuestras realidades sean vistos, analizados y discutidos sin escuchar nuestras voces y sin entender las necesidades y realidades del contexto local.

Fals Borda lo anunció en el Tercer Congreso Internacional de Matemáticas realizado en abril de 2002:

En nuestro país, como en otros, los efectos del eurocentrismo siguen teniendo vigencia, en vista de la desorientación que se experimenta con frecuencia en las universidades y centros tecnológicos, educativos y culturales en relación con el papel de la ciencia y la responsabilidad que tienen los científicos de ocuparse en el estudio y análisis de las causas de lo que viene ocurriendo en nuestras sociedades y territorios. Estas 
instituciones suponen cumplir a cabalidad con su cometido transfiriendo conocimientos obtenidos de frente a realidades correspondientes a otras latitudes diferentes de nuestras realidades (Fals, 2013, p. 199).

Sintetizando lo anterior podemos afirmar que para Fals Borda el logro del diálogo entre los diferentes tipos de conocimiento requiere igualar los conocimientos, el que viene del extranjero con el local. Pero esto requiere primero creer en el conocimiento propio, tanto el popular como el sociológico.

Vemos entonces como la necesidad de encontrar otra manera de analizar, observar nuestras realidades hicieron que se construyera un paradigma científico alterno que plantea según el autor:

(...) la posibilidad de crear y poseer conocimiento científico en la propia acción de las masas trabajadoras: que la investigación social y la acción política, con ella, pueden sintetizarse e influirse mutuamente para aumentar tanto el nivel de eficacia de la acción como el entendimiento de la realidad. Tomando en cuenta que "el criterio de la corrección del pensamiento es, por supuesto, la realidad", el último criterio de validez del conocimiento científico venía a ser entonces, la praxis, entendida como una unidad dialéctica formada por la teoría y la práctica, en la cual la práctica es cíclicamente determinante (Fals, 1978, p. 273).

La praxis entonces contiene en sí misma un alto componente político, ya que la idea fundamental es producir conocimiento que tenga relevancia para la práctica social y política. Se pretende que al vincular a nuestro medio la teoría a la práctica, es decir se consolide la praxis, será mucho más fácil la transformación de la realidad. El paradigma alterno planteado por Fals Borda se define a través de tres aspectos puntuales: 1) el rol del investigador es fundamental, ya que hace parte activa del proceso de investigación de esa realidad, es sujeto y objeto de la misma, 2) confirma la validez del saber popular en la construcción del conocimiento situado sobre una realidad local, regional o universal y 3) la praxis como el motor para la transformación de dicha realidad.

Para la puesta en práctica de este paradigma alterno Fals Borda plantea una nueva metodología de investigación, la cual da valor a la práctica y a la participación. Cardona lo plantea de la siguiente forma: 
Esta nueva forma de investigar es una vivencia que transforma las relaciones entre el investigador y el investigado, entre estudiante y maestro, superando por completo tales dicotomías, poniendo como prioridad la producción de conocimiento a partir del diálogo con quienes construyen la realidad, que se entiende como propia de los sujetos que participan en la construcción de conocimiento social. En ese sentido, tanto la labor investigativa como la labor pedagógica de construcción del conocimiento, reconocen a los sujetos que hacen procesos sociales y los reúne en la búsqueda y consolidación de propuestas transformativas de su compartida realidad (Cardona, 2014, p. 1).

Lo fundamental es la «confrontación con la realidad, para enriquecer la expresión con la práctica y la teoría con la acción» (Fals, 1978, p.269). Un conocimiento social crítico y transformador para Fals Borda es aquel que surge de la interrelación entre realidad, teoría, practica y acción; un conocimiento que permita la superación de las propias necesidades surgidas desde las realidades locales. Un conocimiento que sea subversivo, es decir que sea construido desde las mismas bases sociales y que rompa con las estructuras de dominación. Para ello dedicaremos el siguiente apartado en el que analizaremos su propuesta en torno a la investigación como motor para el logro de ese conocimiento social crítico y transformado

\section{El conocimiento alterno: praxis, realidad y transformación de la realidad}

Fals Borda señala que en la búsqueda de crear y poseer conocimiento científico alterno a partir de ese saber popular, de ese sentido común, propio de la acción misma encuentra en la praxis la respuesta. El autor entiende la praxis como como una unidad dialéctica formada por la teoría (preconceptos, ideas preliminares o informaciones externas relacionadas con procesos, hechos, tendencias que se observan en la realidad) y la práctica (aplicación de principios o de información), en la cual la práctica es cíclicamente determinante (Fals, 1978, p. 275).

Fals Borda confirma la validez del saber popular como fundamento para comprender la realidad al afirmar que para obtener y crear conocimientos científicos, para identificar y reconocer el papel de los actores sociales como protagonistas históricos, la incidencia que juega la sabiduría popular, el sentido común, y la cultura de un pueblo son fundamentales en los procesos de construcción del conocimiento de un conocimiento que permita la transformación de la realidad de esos actores. 
El concepto de realidad y su reconocimiento ha sido una reflexión constante de la filosofía a lo largo de la historia de la humanidad. Cuando nos referimos al concepto de reconocimiento de la realidad decimos que toda actividad humana está orientada hacia dotar de sentido tal realidad. Y tal y como señala Fals Borda cuando se quiere investigar la realidad es necesario comprender el sentido que los colectivos le dan a sus acciones y a su contexto, tener en cuenta el componente volitivo. Por lo tanto, la realidad es un modo de sentir humano, algo a lo que se le puede formar, dar respuestas y sentidos culturales distintos. La realidad es cambiante y susceptible de ser transformada que no está hecha por otros sino por nosotros mismos. Es decir, se investiga la praxis, las acciones de los actores sociales, sus creencias y el sentido que le dan a la realidad.

La posibilidad de construir conocimiento atendiendo a ese "saber popular", al producto de la acción misma, de la práctica se puede analizar a partir de la relación entre la teoría y la práctica y también a partir de sus reflexiones acerca de los compromisos de los científicos sociales. Es decir, frente al rol del investigador y al estatuto de validez del saber popular el autor enunció las bases gnoseológicas sobre las cuales se intenta superar permanentemente la dicotomía conocimiento y la acción, teoría y práctica. (cfr. pág. 256):

1. El Problema de la relación entre el pensar y el ser: el cual se resuelve por la observación de lo material que es externo a nosotros e independiente de nuestra conciencia y lo material incluye no solo lo constatable de la naturaleza sino también las condiciones de la existencia humana.

2. El problema de la formación y reducción del conocimiento, el cual no se resuelve diferenciando los fenómenos de las cosas-en-sí, sino planteando la diferencia entre lo que es conocido y lo que todavía no se conoce.

3. El problema de la relación entre el pensar y actuar se resuelve reconociendo una actividad real de las cosas a la cual solo se adviene por la práctica que, en este sentido, es anterior a la reflexión; allí se demuestra la verdad objetiva, que es la materia en movimiento.

4. El problema de la relación entre forma y contenido se resuelve planteando la posibilidad de superar su indiferencia por la práctica y no solo por el comportamiento intuitivo o contemplativo. 
Bases cuya relación plantean la ruptura del paradigma positivista en el que se pretendía que todo fuese medido desde la rigurosidad del método científico positivista y bajo unas reglas homogenizantes que anulan al científico como parte del universo, inserto en un mundo social e histórico que lo permea. Es decir, el quehacer científico es también praxis.

Una vez se ha valorado nuestra producción de conocimientos, podemos entablar un diálogo de saberes y la confrontación dialéctica. Solamente reconociendo nuestra realidad, investigándola, ahondando en su historicidad, se lograría una verdadera universalización. Partiendo de lo que somos sabremos para donde vamos, y eso solo se logra si la producción de conocimiento va ligada a procesos de reconocimiento de las realidades de sus participantes, se supera la dicotomía del sujeto -objeto de investigación por sujeto- sujeto. Estos sujetos son activos dentro del proceso de investigación no agentes pasivos, sino que hacen parte del cambio, de la transformación misma de la realidad y de sus condiciones. Darío Botero citando al maestro Fals Borda afirmó en su libro El derecho a la utopía, que:

La universalidad se alcanza con el rigor, la profundidad del análisis, la especificación y clarificación teórica de una realidad propia y su expresión. Esto es, que "sólo profundizando en nuestra identidad alcanzaremos la universalidad concreta. Los intelectuales latinoamericanos son colonizados por su propia voluntad, se sienten herederos de una realidad que no es la suya, aman una cultura que no viven; su existencia se desenvuelve en la dispersión de su propio ser enajenado; se reconocen en un mundo que los niega y niegan el mundo que podría afirmarlos (Botero, 1997, p. 26).

La herencia de una realidad que no es nuestra, que no ha tenido en cuenta las voces de todos los que hacemos parte de ella ha propiciado un desarraigo cultural que ha permeado la producción de conocimiento misma. Como lo afirma el autor «necesitamos, construir paradigmas endógenos enraizados en nuestras propias circunstancias que reflejen la compleja realidad que tenemos y vivimos» (Fals, 2013, p. 202).

Cuando se exportan a los países subdesarrollados no solo las técnicas alienantes sino los mismos productos terminados, o "envasados", se registra un fuerte impacto cultural que barre los propios valores, haciendo olvidar aquellos elementos del folclor que constituyen lo que se ha dado en llamar la "esencia de la nacionalidad". Se va borrando así la "filosofía espontanea", el lenguaje, el sistema de creencias y el sentido común 
tradicional de los habitantes de esos países pobres para suplantarlos por otros que son xenofílicos e inauténticos. Así se limitan también las posibilidades raizales de producir e inventar en el campo científico y tecnológico. (Fals, 2013, p. 206).

Para cerrar este apartado, mencionaremos por último el lugar privilegiado que Fals Borda le da a la transformación de la realidad. Si investigamos la realidad, no es sólo para entender las dinámicas sociales, sino para transformarlas. Para el autor este conocimiento de la realidad implica una investigación activa por parte de las comunidades.

El propósito de este es producir conocimiento que tenga relevancia para la práctica social y política; no se estudia nada porque si (...) En la investigación activa se trabaja para armar ideológica e intelectualmente a las clases explotadas de la sociedad para que asuman su papel como actores de la historia. Este es el destino final del conocimiento. La construcción de conocimiento es colectiva, es a su vez una experiencia pedagógica política, y debe ser para conocer la realidad, organizarse y hacerle frente en la práctica a los grandes problemas de miseria, violencia e injusticia (Fals, 1978, p.279).

Vemos como la producción de conocimiento que tiene en cuenta ese saber popular, y que permite la participación de los actores sociales a partir de procesos de investigación que se desarrollan desde la acción misma dentro del marco de un paradigma alternativo como lo plantea Fals Borda constituye el fundamento para lograr una transformación de la realidad. Se investiga en la praxis para la praxis, es decir se vincula conocimiento y acción.

\section{Investigación acción participativa}

La investigación acción participativa es la propuesta que nos plantea Fals Borda para el logro de esa transformación de la realidad, de la consecución de un pensamiento crítico a partir de la producción de conocimiento que se dé a partir de este modelo de investigación. Se vislumbra como un paradigma emancipatorio cuya corriente de pensamiento busca desde su accionar metodológico un conjunto de prácticas sociales intencionalmente dirigidas a la transformación de las estructuras injustas y orientadas desde visiones del futuro alternativas a los modelos hegemónicos. Sabemos que estos paradigmas surgen debido al agotamiento que produce la inequidad, la injusticia como resultado de los modelos económicos vigentes. 
En el Congreso de Convergencia Participativa que se hizo en Cartagena en el año de 1995 se determinó como premisa que hacer una investigación participativa era aceptar que toda investigación es interacción comunicante, en la que ocurre un proceso de diálogo, de aprendizaje mutuo y de mutua confianza entre el investigador y el investigado. De esta manera se cierra la brecha entre lo subjetivo y lo objetivo.

La investigación Acción Participativa IAP es una metodología que surgió del debate en una nueva época de auge de la sociología colombiana a comienzos de la década de 1960. Se abrió paso en el mundo académico producto de los profundos y cualificados resultados obtenidos tanto para las comunidades como para el mundo académico (Cardona, 2014).

La investigación acción pretende dar luces sobre la manera de identificar, clarificar y resolver situaciones problemáticas en la práctica misma. Factor decisivo en el análisis del presente trabajo, ya que es lograr comprender cómo desde la práctica misma podemos teorizar y no como siempre hemos estado acostumbrados debido a la fuerte influencia del positivismo que requiere teorizar, o para el caso de Latinoamérica usar teorías elaboradas por otros, para luego aplicar.

La experiencia del país en la aplicación del modelo de Investigación Acción, definida por Fals Borda surge esencialmente para «llamar la atención sobre el "compromiso" de los científicos colombianos y de los intelectuales en general ante las exigencias de la realidad del cambio social» (Fals, 2013, p. 207) en los años 60 poniendo en evidencia la mirada positivista de la ciencia y sus implicaciones sociales.

La IAP, se diferencia de otras formas de trabajo científico esencialmente porque: a. posee una estructura valorativa o ideológica con actitudes críticas relacionadas con el conocimiento y su utilización, el contexto social y patrones culturales en vías o en necesidad de mejoramiento y cambio. b. una batería de técnicas de encuesta multidisciplinarias combinables, derivadas de una sola lógica inmanente de investigación científica y de una epistemología holística o extensa (Fals, 2009).

Es entonces la investigación participativa un método en el que la acción es fundamental para la obtención de resultados que den repuesta a las necesidades y al mejoramiento de la calidad 
de vida de las colectividades que la aplican, en palabras de Fals Borda hace parte de una "filosofía altruista de la vida".

Para Fals Borda cualquier trabajo de investigación que se lleve a cabo bajo este método debe tener claridad frente a (Fals, 2009, p. 326-329):

1. Que no se busca la determinación de leyes sociales, pueden existir desarrollos previsibles los cuales se encuentran sujetos al tiempo, al lugar y a la cultura. No hay predicción absoluta.

2. Que existen dos polos dentro del espectro de las ciencias: uno cosmológico abstracto y otro donde se colocan los proyectos participativos, locales coyunturales y valorativos. No se pueden comparar los dos polos.

3. Que el rigor investigativo no se juzga solo con mediciones cuantitativas, aunque éstas puedan ser necesarias en la descripción y explicación de los resultados del trabajo. Las mediciones deben matizarse con descripciones cualitativas pertinentes que son igualmente válidas y necesarias.

4. Que, por la fluidez natural de los fenómenos sociales, culturales, económicos y políticos, es necesario abrir el compás para diversas series de interpretaciones y reinterpretaciones, hay que verlos como como procesos históricos sujetos a análisis hermenéuticos.

5. Que todos los métodos, y técnicas de las ciencias son legítimos de aplicar en la investigación participativa siempre y cuando ello encaje dentro del marco de referencia acordado.

6. Que la empatía y la observación participante son de las técnicas más apropiadas para investigar la naturaleza de las situaciones que más interesan a la investigación participativa.

7. Que los criterios de validez para trabajos de la IAP dependen no de pruebas de correlación interna de variables o ejercicios “objetivos" o cuantificables, sino del examen inductivo/deductivo de resultados determinables por la práctica, por el desarrollo empático de procesos sentidos desde las realidades mismas, por el juicio ponderado de grupos de referencia locales, y por el sentido común. 
8. Que la evaluación de resultados no se ejecuta necesariamente al término de un periodo dado o prefijado por el conocido ritmo de la reflexión-acción, como si fuera lineal, sino que puede darse en la marcha misma del trabajo de campo, como estímulos de la acción.

9. Que, a causa de las diversidades y contradicciones existentes en el mundo real, cuya observación implica enfocar atributos dependientes o variados, es necesario que los valores, metas y compromisos que animan al investigador o investigadora participativos sean transparentes, y que se hagan explícitos en los marcos de referencia y en los trabajos de campo.

10. Que no hay lugar para la experimentación a la manera de las ciencias naturales que permiten la repetitividad del fenómeno, sólo hay margen para formas de comparativas de inducción y deducción sujetas a espacios y tiempos determinados. Por lo tanto, no pueden existir "casos típicos" o "proyectos piloto"; solo hay interpretaciones teórico-prácticas probablemente generalizables.

11. Que al recibir y considerar sin prejuicios la sabiduría popular y el sentido común, el conocimiento académico interdisciplinario puede propiciar críticamente una comprensión holística o más completa de la realidad y así enriquecer formas y estilos de la comunicación con las comunidades estudiadas.

12. Que el rompimiento de la díada investigador /investigado para quebrar la asimetría y horizontalizar la relación no significa el predominio intelectual de uno u otro, sino la posibilidad respetuosa de los aportes mutuamente fructuosos por evidencias y hechos confrontables.

13. Que en determinadas circunstancias conviene distinguir entre la racionalidad investigativa y la racionalidad política y no mezclarlas indiferentemente.

14. Que las técnicas de demostración en prácticas de extensión o para inducir cambios estructurales se limitan por factores económicos y por falta de persistencia: debido a que los procesos participativos son casi siempre a mediano y largo plazo, por ello se requiere vincular a instituciones interesadas.

15. Que, si el trabajo de campo lleva a niveles macro de movilización política, social, económica y/o cultural, es importante proceder desde la bases. 
16. Que el paso analítico de la participación de una escala micro a una macro no solo se puede realizar, sino también calibrar y relacionar con la emergencia de movimientos sociales, redes y organizaciones que no sean manipulables.

17. Que la objetividad y la subjetividad pueden coincidir en el arte, en la imagen y en la expresión literaria y estética del trabajo científico, lo que justifica la incursión creadora de la imaginación y la expresión.

Para el análisis de la realidad circundante y de la construcción de esos paradigmas endógenos que reflejen las verdaderas necesidades locales, regionales y nacionales y que permitan una transformación de las mismas la Educación juega un papel fundamental de ahí la necesidad de retomar lo que Fals Borda plantea frente al rol que juega la educación en la construcción de conocimiento de la realidad y sus aportes en la transformación de la misma. Para ello dedicaremos el siguiente apartado.

\section{Papel de la educación en la transformación de la realidad}

Para desarrollar este apartado me apoyaré en Javier Ocampo quien en su artículo: El maestro Fals Borda sus ideas educativas y sociales para el cambio en la sociedad colombiana, aterriza la propuesta de Orlando Fals Borda para la educación media ya que Fals Borda hizo aportes significativos particularmente en lo que se refiere a la Educación Popular y Universitaria.

Que la educación fomente la creatividad de los educandos y la constante dinámica educativa a través de la escuela activa y participante, estimular a los educadores para que tengan mayor decisión en las tareas de investigación participativa que se necesitan para conocer mejor la realidad escolar y comunitaria, para vincular y motivar a los y las estudiantes de todas las edades, hasta el punto de que lleguen a ser gestores de su propio aprendizaje, y para afirmar el papel de liderazgo y orientación colectiva que tienen los maestros (Ocampo, 2009, p.33).

Este señalamiento que hace Javier Ocampo citando al maestro Fals Borda cuyo análisis se desprendía de la situación colombiana en la década del 60 y que se esperaría su aplicación y que hubiese producido cambios significativos en el sistema colombiano de educación, vuelve y se acuña a nuestra realidad actual; si bien se han producido cambios estos no han sido de trascendencia 
debido a que el modelo educativo sigue respondiendo a las necesidades del modelo económico imperante por lo que procesos como en su momento la escuela activa, no dieron los resultados que se esperaban al interior de las comunidades. Continuamos ajenos a las necesidades de la comunidad, solo esperamos cubrir las expectativas de un Estado que aplica modelos de evaluación exógenos pero que espera que todos podamos dar cuenta de ello sin atender a las verdaderas necesidades y condiciones del territorio.

La producción de conocimiento está dada desde la investigación, de ahí que la educación debe estar cifrada por la indagación, siendo claro que el conocimiento no es estático, sino que se encuentra en continuo movimiento. Por lo tanto, lograr que el Colegio CODEMA IED se conciba como un centro de indagación llevará a una verdadera comprensión de la naturaleza de sus problemas y de esta manera se fomentarán los ideales de emancipación, participación y reflexión sobre su propia realidad y la realidad de sus estudiantes. Es a través de la investigación, la indagación en el aula que lograremos un verdadero proceso emancipatorio, es en el reconocimiento de nuestra realidad y su estudio juicioso, sistemático y reflexivo que permitirá que los y las jóvenes del Colegio CODEMA IED logren fortalecer su pensamiento critico.

El logro de una educación humanista para cualquier contexto educativo como lo plantea Javier Ocampo citando a Fals Borda:

Es una experiencia vital que comprende todos los procesos de asimilación mental y proyección del pensamiento, aquellos que permiten al hombre formarse una filosofía y una capacidad de acción social, sea como persona o como miembro de una colectividad. Este enfoque coloca a la educación dentro de la sociedad, al descubrir la dimensión clasista en el proceso educativo; rompe el esquema del profesor tirano enfrentando al alumno pasivo y deja a aquel más bien frente a grupos sociales. El descubrimiento de la dimensión de clases lleva a la acción, es decir, a decidirse por diversas opciones que la realidad le va ofreciendo, con el fin de transformar revolucionariamente esa realidad (Ocampo, 2009, p.35).

Somos el reflejo de lo que los grupos dominantes han querido forjar. Estos grupos han utilizado la educación para consolidar su poder económico, reforzar su situación social y racionalizar su actividad política (Ocampo, 2009). Un factor que menciona el autor y que es de trascendencia para el logro de transformación de la realidad es el que tiene que ver con la dimensión 
de clases; cuando el maestro y sus estudiantes logran identificarse como seres activos dentro de su condición social, a ejercer su poder, su dimensión política, es cuando estos logran transformar su realidad, si es un agente pasivo depositario de información muy seguramente las clases dominantes y el modelo económico imperante seguirá actuando sin reparo de las condiciones, necesidades de su comunidad.

Entonces para lograr una transformación de la realidad se requieren tres aspectos puntuales: 1. Que la producción de conocimiento tenga en cuenta el saber popular, esas voces que se abren paso en las comunidades. Que se produzca entre sujetos activos del proceso de investigación. 2. Que haya una metodología que contribuya al reconocimiento de esa realidad desde la acción misma, desde la práctica misma. 3. Que sus actores se asuman como sujetos políticos que comprenden su dimensión de clase.

Ocampo citando a Fals Borda señala de igual manera que esa transformación de la realidad requiere con urgencia que haya:

Una reevaluación de "lo propio" en nuestras fuentes culturales: los conocimientos, técnicas, costumbres y creencias en las que se enraíza nuestra personalidad como colombianos. Es necesario rescatar lo autóctono y tratarlo con respeto y admiración, porque lo que es propio tiene una profunda razón de ser y de ello depende nuestra supervivencia. La tendencia a imitar lo externo es grave porque nos convertimos en seres sin personalidad; nos lleva a ser miembros de una sociedad de consumo que alimenta una maquinaria de propaganda internacional y nacional (Ocampo, 2009. p.38).

Se ha mencionado anteriormente la necesidad de que la producción de conocimiento requiere de procesos de investigación pero que estos se gesten desde la acción misma, y que requieren de la participación activa de sus protagonistas que se dimensionan como actores políticos y gestores de cambio y que sus acciones redundan en la transformación de su realidad haciendo un reconocimiento de sus raíces, de su cultura y del valor que esta posee en la construcción de una identidad.

La ignorancia sobre nosotros mismos, sobre nuestro origen, nuestro devenir histórico, nuestra geografía, nuestros recursos naturales, entre otros; más pronto que tarde, nos llevará a convertirnos en el gran mercado de productos y tecnologías de países 
poderosos y, sin que nos lo propongamos, en promotores de una economía de consumo (Fals, 2013, p. 202).

En este camino de encontrar respuestas a si es realmente importante que la educación y la producción de conocimiento logren un verdadero reconocimiento de la realidad "local" y una transformación de ella encontramos que, pese a décadas de haber debatido interrogantes como este, aún persisten porque nuestras sociedades no han logrado que sus modelos educativos den respuesta a ello. De ahí que Fals Borda sigue y continuará vigente hasta que su discurso sea una realidad.

El maestro Orlando Fals Borda le apostó a la construcción de una sociología propia que diera cuenta de la realidad latinoamericana y sus problemáticas; se fundamentó en la Investigación acción participación (IAP), un método que parte de que el saber se construye en la interacción con las comunidades, buscando lograr la emancipación de las mismas; de esta manera visibiliza el poder popular, el poder de los jóvenes, de los campesinos, de las mujeres, entre otros como el motor necesario para la transformación de un orden diferente al establecido por el capitalismo, sus posturas nos aportan un mundo de posibilidades epistémicas conducentes a construir un verdadero sentido de la educación.

\section{Aportes de los teóricos de la Investigación acción}

Como hemos venido analizando Investigar la praxis es un ejercicio estrechamente vinculado a la posibilidad de comprender nuestra realidad y de transformarla. Fals Borda escribió y reflexionó sobre la educación, sin embargo, para el contexto de la educación básica la perspectiva que ha profundizado en este tipo de investigaciones en el ámbito del aula escolar es la investigación acción, conocida como IA.

La IA es un modelo metodológico que nos acerca a las realidades locales desde las bases donde todos hacen parte de la investigación. Su aplicabilidad en el campo educativo ha sido crucial, por ello retomaremos autores como James Mckernan y Donald Shön quienes abordan la Investigación Acción desde el currículo y el profesional reflexivo en educación.

James Mckernan en su apartado: El análisis del discurso y métodos de investigación en la resolución de problemas publicado en su Libro Investigación Acción y Currículo: Método y discurso en el año de 1999 señala que: «Una escuela que es solo distribuidora de conocimiento no 
sirve para liberar a los profesores y a los alumnos y alumnas, sino para sumirlos en la esclavitud, pues les priva de sus derechos intelectuales». Un profesor que investiga seguramente será un maestro que tiene claro que la tarea de enseñar no requiere llenar la cabeza de los y las estudiantes de información, sino que por el contrario los convoca a aprender a investigar y a pensar racionalmente de manera crítica y reflexiva por sí mismos. Para Mckernan en el mismo apartado «los avances en el conocimiento no se producen por los esfuerzos del carisma o las destrezas de un individuo, sino que son el resultado colectivo de la comunidad de discurso y de investigadores en ese campo» (Mckernan).

Este es un llamado a que los docentes seamos indagadores de nuestra propia práctica, porque es allí donde radica el verdadero éxito de la investigación acción, usualmente se ha pensado que el maestro o la maestra en el aula solo repiten las teorías promulgadas por otros y que por ello están impedidos para construir conocimiento desde su propio quehacer. «Bajo esta perspectiva los maestros son la ruta para la emancipación, ya que evita el rol de autoridad/experto en favor de la creencia de que el conocimiento es provisional y de tanteo» (Mckernan, 1999, p.74).

De ahí que según Mckernan en el mismo apartado antes mencionado señale que:

La investigación no se debe considerar de manera monolítica como el trabajo que el científico espacial hace en el laboratorio, o el que realiza el científico social que pasa largas horas en las bibliotecas para encontrar finalmente material de referencia para la redacción de una pieza de investigación básica o de "despacho". La indagación en la acción es diferente de este enfoque tradicional para la investigación. El contexto político es crucial. Uno de los primeros puntos de partida debería ser un análisis de las limitaciones sobre la propia acción. (...) Su objetivo central es la mejora de la calidad de vida en el entorno de la investigación (Mckernan, 1999, p. 73).

Mckernan afirma que los profesionales en ejercicio son tanto productores como consumidores de investigación, ya que no se hacen distinciones entre «la práctica que se está investigando y el proceso de investigarla. Es decir, enseñar e investigar en la enseñanza no constituyen actividades distintas» (Mckernan, 1999, p. 23).

Un maestro reflexivo que advierte la necesidad de mejorar su práctica educativa y/o de transformar las realidades de sus estudiantes, muy seguramente empleará el modelo de 
investigación acción, el cual da valor a su quehacer pedagógico y a lo que hacen y viven sus estudiantes.

Es de suma importancia considerar al maestro como sujeto político, es reconocer que el maestro tiene la potencia para ser. No es solo un objeto al servicio de los condicionamientos de un sistema que espera que funcione de acuerdo a sus intereses. Por lo tanto asumir a los maestros como un colectivo en el que se generan vínculos, disensos, consensos y que desde estos se construyen discursos (lexis) y acciones (praxis) que buscan la transformación de sus realidades, es reconocer que su papel va más allá de la sola apropiación de un saber o de la elaboración teórica y su reflexión, sino que además combinan la acción con el firme propósito de luchar contra las injusticias y de esta manera se convierten en actores críticos y transformadores de las realidades propias y circundantes.

Traigo a colación un apartado muy especial descrito por las autoras Piedad Ortega, Diana Peñuela y Diana M. López, en uno de los capítulos de su libro Sujetos y prácticas de las pedagogías críticas que corroboran que:

Los maestros como intelectuales, investigadores transformadores no son colectivos que se dedican de manera exclusiva a la contemplación e interpretación del mundo donde están inmersos, sino que sus investigaciones son producto de sus reflexiones y actuaciones en la esfera pública de la escuela, pero además generan procesos que afectan la dinámica al interior de los mismos en perspectiva de una transformación radical de la realidad que agobia a todos los agentes de la escuela. Asumirse como intelectuales, significa ubicar una posición que reflexiona y trasciende en busca de la finalidad que persigue la eliminación de las desigualdades, las injusticias sociales y los desequilibrios generados por el capitalismo (Piedad Ortega, Diana Peñuela y Diana M. López, 2009, p. 95).

Ahora bien si partimos de que los participantes son quienes mejor experimentan los problemas, para el caso de los maestros son ellos quienes desde su quehacer reflexivo acentúan la fuerte concepción del maestro como investigador ya que es claro que las disciplinas convencionales no han dado todas las respuesta a las problemáticas que se gestan de la práctica en la enseñanza y aprendizaje mismo. 
Mckernan (1999) plantea que la concepción del profesor como investigador ha pasado en las últimas décadas de la resolución de problemas, que utiliza herramientas de medición cuantitativas, a la investigación naturalista que utiliza diseños descriptivos- esclarecedores basados en el estudio de casos y los diseños antropológicos sociales (p. 27). Para el autor este cambio se centra en el saber del profesor y en que "Debemos mojarnos los pies en el agua de la práctica" (p. 75). Es a través de la investigación, la indagación en el aula que lograremos un verdadero proceso emancipatorio, a partir de la comprensión de la realidad de los estudiantes y de los maestros.

Otro de los autores en los que quise apoyar esta investigación es Donald Shön que al igual que James Mckernan han tratado sobre el profesional reflexivo y la investigación acción. Graduado de la Universidad de Harvard con una tesis doctoral sobre John Dewey. De John Dewey retomó la idea rectora de "aprender haciendo" y con base a dicho axioma construyó su propuesta. en su libro El Profesional Reflexivo, afirma que para el positivismo el conocimiento práctico « había que ser construido como conocimiento de la relación de los medios con los fines» (Shön, 1998, p. 42) Es decir se reduce el conocimiento práctico a una cuestión simplemente instrumental sobre los medios que más se adecuan para cumplir con un fin determinado, por lo que se da una separación entre aquellos que crean las teorías y quienes las aplican, imponiendo un status a la investigación, la cual desde esta perspectiva solo pertenece a cierto grupo élite y de manera peyorativa se delegó su aplicabilidad a otros que no cumplían con un aprendizaje superior que suponía se debía tener .

Para este autor el conocer se da desde la acción misma, da cuenta de ese sentido común, es eso que Shön llama "saber más de lo que podemos decir" y que es desde este conocimiento que nosotros emitimos juicios, apreciaciones. Donald A. Shön (1998, p. 60) plantea que este saber tiene las siguientes propiedades:

1. Hay acciones, reconocimientos y juicios que sabemos cómo llevar a cabo espontáneamente; no tenemos que pensar sobre ello previamente o durante su ejecución.

2. A menudo no somos conscientes de haber aprendido a hacer estas cosas; simplemente nos encontramos haciéndolas.

3. En algunos casos fuimos conscientes una vez de las comprensiones que más tarde fueron internalizadas en nuestra sensación de la acción misma. En otros casos podemos no haber 
sido nunca conscientes de ellas. No obstante, en ambos casos, normalmente somos incapaces de describir el saber que nuestra acción revela.

Sobre esta base encontramos que ese "saber popular" o "filosofía espontánea” que surge cotidianamente en las aulas encuentra su validez dentro de la práctica misma como generadora de conocimiento. Es la conjunción de todos esos saberes, la sistematización de esas experiencias la que redundará en el reconocimiento y transformación de la realidad de quienes hacemos parte de ella. La construcción de un pensamiento solo es posible a partir del diálogo entre quienes, desde sus singularidades y diferencias, compartimos la voluntad e interés de transformar la realidad en función de un futuro distinto.

Estos autores desde diversos enfoques confluyen en que ese conocimiento de la realidad, esa investigación de la misma será la que realmente genere transformaciones desde lo personal, local y porque no regional y nacional. Además, convergen en que esa participación activa en el proceso de investigación de la realidad conduce a la construcción de una identidad con su cultura, su historia, sus raíces, porque logran conocerla desde sus particularidades mismas, porque se visibilizan y se desvanece el velo del eurocentrismo.

Dado que también se hace necesario reconocer los aportes propios de la aplicación de la IAP en el marco educativo, hemos retomado algunos elementos que autores como James Mckernan hacen con referencia a la investigación participativa asociada principalmente al papel del maestro y al valor de la investigación en la educación.

En la introducción al libro Investigación-acción y currículo James Mckernan afirma que el propósito de la investigación acción en relación a la investigación tradicional es que mientras la primera busca resolver los problemas diarios e inmediatos de quienes lo requieren, la investigación tradicional tiene como meta la redacción de informes o publicaciones.

La investigación acción pretende proporcionar materiales para el desarrollo del juicio práctico de los actores en situaciones problemáticas. La validez de los conceptos, los modelos y los resultados que genera depende no tanto de las pruebas de verdad científicas cuanto de su utilidad al ayudar a los profesionales a actuar de manera más efectiva, más capaz e inteligente. Las teorías 
no se validan con independencia de la práctica y se aplican luego (...), por el contrario, se validan mediante la práctica (Mckernan, 1999, p. 24).

La investigación acción es entonces un estudio riguroso, sistemático por medio de procedimientos científicos en donde los participantes son críticos reflexivos del proceso y los resultados. Como principios fundamentales encontramos entonces:

En primer lugar, que los participantes que experimentan el problema son los que mejor estudian e investigan los entornos naturalistas; en segundo lugar, que la conducta está muy influida por el entorno naturalista en que se produce y en tercer lugar, que las metodologías cualitativas son quizás las más adecuadas para investigar entornos naturalistas (Mckernan, 1999, p. 25).

La idea de que el comportamiento humano es influenciado por el ambiente en el que se produce, genera un campo de acción muy importante, ya que es solo quien conoce y vive en su propio espacio social podrá ser determinante en las posibles soluciones a problemáticas reales y no aquellas que se dan desde agentes externos que solo se sitúan en estos espacios por corto tiempo. Son entonces los y las jóvenes junto con sus maestros los que desde el estudio minucioso, sistemático y riguroso de su realidad que puedan propiciar posibles soluciones o respuestas a sus problemas. Por ende, el fundamento de la investigación acción es que puede resolver problemas prácticos.

Para la implementación de la investigación acción debemos identificar los tres tipos de modelos teóricos sobre los cuales se sustenta según lo planteado por James Mckernan en su libro expuesto en este trabajo:

1. La investigación acción científica: la cual se funda en procedimientos inductivos, es decir plantea una clara inclinación por teorizar y construir modelos conceptuales gráficos. Lewin, exponente de este modelo afirma que: «La investigación acción requiere la participación del grupo por medio de procesos democráticos basados en una planificación, análisis, identificación de hechos y evaluación cuidadosos; por tanto, el fundamento está en la metodología racional sistémica» (Mckernan, 1999, p. 38). 
2. El modelo de la investigación acción práctico - deliberativa: este modelo como una teoría práctica intenta influir en el modo en que las personas se comportan viven su vida, en su modo de sentir y pensar. La meta de estos investigadores es comprender la práctica y resolver los problemas inmediatos. La deliberación práctica responde a la situación inmediata que se considera problemática desde una perspectiva moral; (...) Lo práctico está relacionado también con el proceso antes que con los productos finales de la indagación (Mckernan, 1999, p. 41).

Es claro que los investigadores de la acción concluyen que es crucial que la práctica y la investigación se deberían fundir en una sola. Mckernan afirma que «el investigador de acción desarrolla una comprensión interpretativa personal a partir del trabajo sobre los problemas prácticos y que la comprensión teórica es constitutiva de la acción y el discurso prácticos» (Mckernan, 1999, p. 42). Para este autor:

Es crucial la idea de que (...) la enseñanza son empresas muy teóricas y que la investigación misma es un proceso auto reflexivo en el que se permite a los profesionales en ejercicio examinar su mundo teórico de la práctica, que ellos perciben en términos fundamentalmente muy diferentes a los investigadores profesionales “externos” (Mckernan, 1999, p. 43).

3. El modelo de investigación acción educativa crítica emancipadora: este modelo rechaza « la creencia positivista en el rol instrumental del conocimiento en la resolución de problemas, afirmando que la investigación critica permite a los profesionales no solo descubrir los significados interpretativos que tienen para ellos las acciones educativas sino organizar la acción para superar las limitaciones»(Mckernan, 1999, p. 45). Este modelo da poder político a los participantes permitiendo una verdadera democratización de la educación.

Mckernan en otro de sus apartados del libro antes mencionado afirma que el elemento unificador entre estos tres modelos lo constituye «el que toda investigación acción es una forma de indagación reflexiva regida por rigurosos principios o cánones de procedimiento» (Mckernan, 1999, p.51). No se puede desconocer que la investigación acción posibilita que tanto el profesor como los y las estudiantes se comprometan en la búsqueda compartida de conocimiento y que este último sea susceptible de ser cuestionado, o transformado y que por tanto sea provisional. 
Desmitifica al maestro como el único poseedor de este y amplia el rango de acción de la escuela, una Escuela que aprende.

Como maestro espero que estos jóvenes en los procesos de construcción y asimilación de conocimientos colectivos y derivados del contacto con la vida real, con las circunstancias y con el medio que les rodea permitan que sus descubrimientos e iniciativas sean útiles para su contexto y su comunidad, generando en ellos actitudes reflexivas y críticas frente a diferentes procesos a los que nos avocan los distintos sistemas mundiales económicos y políticos, por ello veo en la investigación acción participativa una propuesta interesante que contribuirá al logro de este objetivo.

Dado que también se hace necesario reconocer los aportes de estos otros autores en la aplicación de la IAP en el marco educativo, hemos retomado algunos elementos que hacen con referencia a la investigación participativa asociada principalmente al papel del maestro y al valor de la investigación en la educación.

Planteo entonces como propuesta que a partir del semillero de investigación en filosofía latinoamericana se valide como un escenario en el que tanto el profesional en educación como sus estudiantes desde sus propias necesidades y realidades busquen la mejora de sus condiciones de vida, desde la observación y vivencia misma, es decir desde la práctica se teorice. «De ahí que el aula o lugar de trabajo se convierte en un laboratorio para someter a prueba, empíricamente hipótesis y propuestas que están en práctica» (Mckernan, 1999, p. 25). Esta es la propuesta que en el capítulo siguiente consolidaré. 


\section{Capítulo 2}

\section{Propuesta Pedagógica}

En este capítulo se plantea la necesidad de una propuesta pedagógica que promueva la generación de conocimiento sobre la base del reconocimiento de la realidad de los jóvenes estudiantes del Colegio CODEMA IED con miras al logro de su transformación y a la generación de un pensamiento crítico, mi planteamiento es que una vía pedagógica idónea es la creación de un semillero de investigación y la sistematización del mismo.

El planteamiento de Fals Borda aporta sustancialmente a la necesidad de reencontrar a estos jóvenes con el conocimiento, no con ese conocimiento generado por la acumulación de información proveniente de otros escenarios, que igualmente son valiosos pero que no son cruciales para la vida de estos jóvenes, sino llevarlos a buscar esa construcción del conocimiento fundado en nuestras raíces. Considero que es el desconocimiento de lo que somos es lo que hace que estos jóvenes no encuentren una verdadera motivación y que los lleve como lo afirma Fals Borda: a «realizar copias e imitaciones impuestas de paradigmas desarraigados del contexto propio» (Fals, 2013, p. 202).

Este desafío implica, reconocer que la simple obtención y transmisión de información o contenidos aun, cuando sean críticas no necesariamente nos lleva a su adhesión como tal. La propuesta parte del principio de la búsqueda por el reconocimiento de los saberes y disposiciones previos, de los sistemas de creencias que todos tenemos, de esta manera que se pueda generar una real curiosidad epistémica en los jóvenes del Colegio CODEMA IED. Esto lo sostengo apoyándome en la propuesta de Fals Borda, es decir un conocer a partir de la práctica es una actividad transformadora que está arraigada en las necesidades concretas de los sujetos. El camino a recorrer es el siguiente: primero valorar los saberes y prácticas de los estudiantes y del docente como una forma de conocimiento válida, segundo mostrarle a los estudiantes que esto es así y que lo que deben hacer es identificar, explicitar y valorar estas formas de conocimiento; tercero fomentar la capacidad de asombro, la disposición, la voluntad de querer pensar desde una perspectiva crítica; cuarto promover el diálogo con otras formas de conocimiento, teniendo mucho cuidado de no repetir el modelo de enseñanza y de producción del conocimiento basado en la 
dicotomía teoría-práctica y de repetición de información. Valiéndonos de este argumento del reconocido pedagogo Paulo Freire en su libro Reflexión Crítica sobre las virtudes del educador (Freire, 2001) afirmó que «Conocer es una actividad viva, lo contrario no es conocer, es solo tragar momias conceptuales y luego escupirlas ante alguien que solicita esa tarea para avalar que el conocimiento existe en quien repite lo que le enseñaron (no lo que aprendió)» (Freire, 2001, p. 50).

Los y las estudiantes del Colegio CODEMA IED traen consigo una serie de "saberes" que, si al tomarse en cuenta y como lo afirma Fals Borda al darle validez a estos, para confrontarlos, interrelacionarlos, con su realidad local, muy seguramente la producción de conocimiento y por sobre todo su involucramiento con este se lograría. Es aquí donde se ha fallado, hemos erigido el conocimiento sobre algo externo a nosotros, que no hace parte de lo que somos y que no tiene en cuenta las voces de todos los que participamos en su construcción, de ahí que solo se derive en información que hacen otros y que solo sirven para medir la capacidad de retener o memorizar.

La propuesta del semillero busca a dar cuenta de las necesidades de nuestro contexto, de nuestras realidades, y de promover parafraseando a Fals Borda la interacción de la sociedad con el medio social y natural, con el conocimiento de nuestra historia, nuestros recursos llevando al fortalecimiento de nuestra identidad cultural como generadora de solidaridad entre todos. (Fals, 2013). Esto no significa desconocer los aportes que desde otros hemisferios nos han hecho. No podemos llegar a una verdadera transformación si seguimos copiando los esquemas de otros contextos. No se trata de aislarnos del mundo intelectual externo sino de potenciar el diálogo entre conocimientos producidos en contextos diferentes.

El semillero de investigación tiene como fin promover la participación, la capacidad creativa y el diálogo entre estudiantes y el docente en la búsqueda de nuevos conocimientos a través de procesos de investigación que atiendan a las necesidades propias del contexto y de respuesta a las mismas. Bernardo Restrepo (2004) en su artículo "Formación investigativa e investigación formativa: acepciones y operacionalización de esta última", hace distinción frente a la formación investigativa y la investigación formativa. Asume que son dos conceptos que comparten semejanzas, pero también diferencias. La investigación formativa implica una actividad investigativa que pretende formar para la investigación desde propuestas y acciones investigativas mientras que la formación investigativa no involucra siempre actividad investigativa ya que puede 
impartirse a través de otras actividades docentes y se da a partir del proceso de enseñanza aprendizaje.

Afirma que el movimiento de semilleros de investigación es otra forma de implementar la investigación formativa o en algunos casos como actividad de la formación investigativa. Cuya práctica fomenta un cambio de la docencia expositiva a formas activas de aprendizaje contextualizado, «buscando desarrollar en los estudiantes la capacidad de preguntarse, problematizar situaciones, documentarse, argumentar, entre otras» (Restrepo, 2004).

Puntualmente el documento nos brinda claridad frente a la diferencia en formación investigativa e investigación formativa, además de ubicar a los semilleros dentro de esta práctica, estableciendo sus objetivos y fines. Para nuestro propósito en primera instancia el semillero de investigación pretende consolidarse desde la formación investigativa, brindando las herramientas necesarias para generar procesos de investigación y luego consolidarnos como grupo dentro de la investigación formativa.

El Sociólogo y Magister en Educación Félix B. Marimón (2009), en su documento “Los semilleros como espacio de iniciación en investigación", define los semilleros de investigación como «una iniciativa integradora y facilitadora de procesos grupales en los cuales participan diversos actores, permitiendo un diálogo enriquecedor tanto académico como vivencial» (Marimón., 2009). El autor plantea que los semilleros de investigación deben constituirse en espacios de resistencia, ya que estos deben promover la investigación a partir de cambios conceptuales y morales en los estudiantes.

Marimón cuestiona de manera explícita la naturalización de la sociedad y los saberes a través de las ciencias sociales como producto de la modernidad. Para ello cita autores como Dussel (2006), Quijano (2000) y Grosfoguel (2006) quienes le permiten sustentar su postura frente al lugar que ocupa la investigación en el pregrado afirmando que es «una especie de tecnología fabricada que se recicla en los discursos de la profesionalización y la investigación, poniéndonos frente a una máquina hacedora de subjetividades que narra el mundo a partir de una clasificación construida desde la razón» (Marimón, 2006:9).

Asumir los semilleros de investigación como espacios de resistencia, proporcionan al desarrollo de la investigación una postura crítica y diferente de la concepción de semillero, 
aportando elementos valiosos para el abordaje de la filosofía latinoamericana como objetivo de estudio del semillero conformado con los y las estudiantes de secundaria del grado decimo y once.

Por otra parte, Luis Fernando Molineros G. (2009) en su "Epistemología de los Semilleros

de Investigación y la Cultura en Red de la Redcolsi", , amplía el panorama frente a la trayectoria de los semilleros desde la Redcolsi, y su incidencia en la cultura investigativa en nuestro país.

El autor afirma que en Colombia no existe una verdadera política de Estado que reforme los sistemas de investigación, y que deseche las viejas costumbres dando paso a estrategias de base que no solo enfaticen en la productividad, sino que prioricen en la formación de capital semilla autosuficiente y eficaz. Para ello plantea «la necesidad de comprender el movimiento de semilleros de investigación como espacios para el diálogo y el intercambio de experiencias entre los actores a partir de la diferencia, que rompen paradigmas no solamente de tipo académico y científico, sino que, además, de tipo pedagógico» (Molineros, 2009).

El documento plantea el semillero de investigación como un proceso de formación para la transformación, guardando cierta relación con Marimón quien asume los semilleros como espacios de resistencia, mientras que Molineros tiende a esperar un producto consolidado más desde el carácter científico y riguroso. No obstante sus aportes frente a la posición que tiene la formación investigativa y la investigación formativa al interior de los semilleros son fundamentales en la construcción del presente trabajo. Incluimos también el valor que da a la vinculación a las Redes, y como estas hacen aportaciones significativas.

En síntesis, se entiende por semillero de investigación una estrategia metodológica que tiene como objetivo la formación en investigación sobre un tema o temas elegidos por un colectivo adscrito a este de manera voluntaria que pueden configurarse como escenarios de resistencia y/o de transformación.

\section{Paradigma guía de la propuesta}

Siguiendo a Mckernan (1999), la investigación formativa abordará la realidad social a través del paradigma interpretativo que rechaza la búsqueda de "fundamentos racionales" y que por el contrario pretende "comprender" la sociedad desde dentro, es decir identificando y

\footnotetext{
1 Redcolsí: Red colombiana de Semilleros de investigación.
} 
reconociendo cuáles son esos movimientos que se gestan internamente en las sociedades, esas subjetividades que se tejen, y que en últimas son expresadas a través de sus acciones. Alejarse, como aconseja el autor, del horizonte positivista que intenta encontrar el mecanismo que dé cuenta del funcionamiento de la realidad, y luego a partir de una teoría con pretensiones de universalidad, comprender realidades concretas, señalar problemas y soluciones, y aplicar correctivos.

La mirada sobre la realidad ha sido permeada por la presencia del enfoque positivista, el cual se visibiliza en los textos escolares, en la idea de aprendizaje y calidad de vida que tienen los y las jóvenes, en los prejuicios que tienen algunos maestros frente a la labor fundamental que tienen áreas como la filosofía, las ciencias sociales, dando solo reconocimiento a las ciencias naturales y a la matemática. Por otro lado, las familias también consideran que si estos jóvenes van bien en estas asignaturas el resto como ellos denominan "son costura". Dando una total relevancia al conocimiento producido en otros escenarios para el caso de los textos escolares, ya que estos en su gran mayoría solo dan la información que se ha generado en la periferia, desconociendo en su gran mayoría lo que se produce al interior de nuestra cultura. Por otro lado, para los maestros y maestras de áreas como la matemática o las ciencias naturales solo lo que se pueden cuantificar y es susceptible de ser comprobado tiene validez. Reconocemos y damos valor a lo foráneo. Aplicamos en los procesos pedagógicos modelos educativos que fueron construidos para otras culturas pero que traemos y sin reconocer nuestras características y condiciones los aplicamos como por ejemplo el modelo mecanicista de la educación que tiene una idea fija de evaluar numéricamente y hacer pruebas estandarizadas sobre lo que deben o no aprender los estudiantes.

Todos los seres humanos poseemos una capacidad de asombro innata, la que nos empuja a preguntar a indagar por cuanto nos rodea, capacidad vital en la producción del conocimiento, pero que pese a que hemos tenido que limitarnos a que sean otros los que investiguen y produzcan el conocimiento gracias al modelo elitista imperante que determina esa clara diferenciación entre los que crean y quienes lo aplican; nuestra institución producto de esta racionalidad instrumental la cual solo espera cumplir unos fines y establecer con claridad unos resultados, ha hecho que las aulas se conviertan en espacios de repetición y memorización de información y no de producción de conocimiento. Con esta preocupación surgió la pregunta que guio esta investigación ¿Cómo lograr que en mi aula de clase se produzca conocimiento? Es evidente que el proceso histórico imperante va ligado en la construcción del conocimiento, en la manera como este se legitime en 
una sociedad, sin embargo, siempre hay opciones: individuos, o colectividades que cuestionan, que confrontan y que hacen que se produzcan ajustes, cambios y que se pueda avanzar hacia otras posibilidades y creo que es aquí donde como maestro me siento confrontado a revaluar mi práctica y a replantear si puedo ser ese agente de cambio y de transformación. Para ello debo lograr comprender la manera como aun cuando no soy un científico social mi experiencia y la sistematización juiciosa de esta pueda hacer parte de esa producción de conocimiento, que además involucre directamente a mis estudiantes. Retomando lo dicho en el capítulo uno sobre Fals Borda y a Shön, se trata de convertirse en un docente comprometido y reflexivo.

El paradigma interpretativo exige un cambio en el dilema sujeto objeto. Álvaro Camacho, quien escribe sobre investigación acción participativa, plantea que es indiscutible que el sujeto y el objeto son realidades distintas «pero que cuando las expresiones humanas y las instituciones se consideran como objetos, es decir como cosas medibles- y por tanto se cosifica el fenómeno de la sociedad, esta cosificación de la sociedad se hace inadmisible» (Camacho, 1986). Por lo tanto, se debe plantear es la relación entre sujeto y sujeto, ya que se trata de personas pensantes y autónomas; por lo que allí el concepto de la participación ya no parcializada sino la que entra a exigir un cambio que conlleva a una transformación personal y social en la que por ejemplo el maestro no va por un lado y los estudiantes por el otro debido a ese grado de sumisión, ya que todos participan en la construcción de ese conocimiento. «Es entonces el grupo que produce el conocimiento, el que lo recibe, el que lo practica, el que lo enriquece. No es el individuo solo ni el investigador solo» (Camacho, 1986).

La propuesta pedagógica y de investigación también intenta abrir un espacio alternativo en el que los horarios, las pruebas, las evaluaciones numéricas, la prelación a la asimilación de la información, la nula atención a procesos de investigación, la escasa participación de los y las jóvenes en la construcción del conocimiento así como la creencia errada de que son otros los llamados a producir conocimiento, se problematicen. Como maestro estoy en la obligación de buscar alternativas distintas que redunden en los cambios y transformación de mi realidad, de la realidad de mis estudiantes.

Tal y como mencioné en el capítulo uno de lo que se trata ${ }_{2}$ siguiendo a Fals Borda 2 es de reconocer sin prejuicios la sabiduría popular y el sentido común junto con el conocimiento académico interdisciplinario para propiciar una comprensión mucho más completa y holística de 
la realidad para que de esta manera se puedan enriquecer las diversas formas y estilos de la comunicación con los y las jóvenes que son razón de nuestro semillero. De igual manera se trata de romper con la diada investigador/investigado para que de esta manera se pueda llevar a cabo una relación horizontal en la que no haya predominio intelectual de uno u otro sino que se genere la posibilidad de que los aportes sean mutuos y fructíferos para todos.

El hecho de reconocer y valorar el saber del otro nos permite reconocer en el accionar mismo de la cotidianidad un producto invaluable en la construcción del conocimiento. Cuando emprendemos las actuaciones espontaneas e intuitivas de las acciones propias de la vida diaria, aparentamos ser entendidos de un modo especial. A menudo no podemos decir que es lo que sabemos. Cuando tratamos de describirlo no sabemos qué decir, o hacemos descripciones que son obviamente inapropiadas. Nuestro conocimiento es de ordinario tácito, está implícito en nuestros patrones de acción y en nuestra sensación respecto a las cosas con las que estamos tratando. Parece correcto decir que nuestro conocimiento se da desde nuestra acción, como lo plantea Donald Shön (1998) en su libro El profesional reflexivo:

Cuando emprendemos las actuaciones espontáneas e intuitivas de las acciones propias de la vida diaria, aparentamos ser entendidos de un modo especial. A menudo no podemos decir qué es lo que sabemos. Cuando tratamos de describirlo no sabemos qué decir, o hacemos descripciones que son obviamente inapropiadas. Nuestro conocimiento es de ordinario tácito, está implícito en nuestros patrones de acción y en nuestra sensación respecto a las cosas con las que estamos tratando (p. 55).

\section{La importancia de la participación}

La propuesta del semillero de investigación también está orientada por las ideas de participación desarrolladas por Fals Borda. Según este autor para conocer se requiere participar en la consecución de un verdadero compromiso de una manera activa en el mundo, es decir dar valor a nuestra capacidad de experimentar el mundo y nuestro compromiso con él como algo significativo, ya que en última instancia es lo que debe producir el aprendizaje. Asumir de esta manera el proceso de conocer y aprender reside en el aprendizaje como participación social, en donde esta última no solo se refiere a los compromisos que se adquieren con su familia y pares sino a los que se adquieren con su comunidad y en la construcción de su identidad en relación con estas 
comunidades. Por ejemplo, formar parte de una pandilla o formar parte de un equipo de trabajo es al mismo tiempo un tipo de acción y una forma de afiliación. Esta participación no sólo da forma a lo que hacemos, sino que también conforma quiénes somos y como interpretamos lo que hacemos.

Así como lo describí en el capítulo uno de lo que se trata siguiendo a Orlando Fals borda es de comprender e internalizar que solo si el trabajo de campo procede desde las bases se lograrán niveles de movilización política, social, económica y/o cultural importantes. Además, que como lo afirma Fals Borda el paso analítico de la participación de una escala micro a una macro no solo se puede realizar, sino también calibrar y relacionar con la emergencia de movimientos sociales, redes y organizaciones que no sean manipulables.

La idea de participación se concibe como la única herramienta capaz de combatir la exclusión política y económica dejando de lado la idea de que esta se da solo con el ánimo de manipular las masas para mantener el statu quo. El hecho de reconocer y valorar el saber del otro, permitirle su participación como sujeto activo en el proceso de investigación posibilitó una verdadera articulación entre el conocimiento académico y la sabiduría popular, lo racional con lo existencial. Esto significa que el conocimiento se concibe como una construcción social y colectiva.

Fals Borda lo dijo claramente, la transformación de una observación experimental a una observación participante posibilitó que ese divorcio existente entre el sujeto y el objeto de investigación se modificara, por lo tanto «la realidad objetiva aparece como "cosas en si” que se mueven en la dimensión espacio - tiempo y que vienen de un pasado histórico condicionante para convertirse en "cosas para nosotros" » (Fals, 2009, p. 265). La necesidad de crear y poseer conocimiento desde los propios estudiantes para ahondar en el reconocimiento de sus realidades les permitirá transformarla.

Hoy día ser científico implica un compromiso que redunda en el futuro de la humanidad, por lo que la ciencia ya no solo es datos y mediciones, sino que ahora hace parte de la comprensión de las realidades. Existe otra ciencia posible inspirada como lo afirma Fals Borda (1978) en una Cosmología "holística” o extensa basada en la participación (p. 308). 
Si bien es cierto en el campo académico años atrás se viene debatiendo sobre el papel de la ciencia y los nuevos paradigmas que se gestan, sin embargo aún en algunas de las aulas del Colegio CODEMA IED continuamos ajenos a todas estas transformaciones. Seguimos regulados por un sistema que nos obliga a cumplir con estadísticas, metas y datos pero que por otro lado vive cuestionando el desarraigo de los y las estudiantes, la falta de innovación, la poca creatividad, la falta de recursividad, y los escasos recursos. Los maestros seguimos discutiendo sobre la necesidad de textos escolares más didácticos, sobre si esta u otra asignatura requiere mayor intensidad horaria por su nivel de complejidad (herencia del positivismo), sobre que debe aprender o no un estudiante para pasar de un grado a otro. Preguntas como: ¿Cuál es el tipo de conocimiento que queremos y necesitamos en nuestra colectividad?, ¿Para quienes es ese conocimiento y a quien va a beneficiar? ¿Cómo producir conocimiento en nuestra institución?, entre otras son preguntas olvidadas y poco tenidas en cuenta. Como maestro soy consciente de que he dejado de lado inquietudes como estas, que, aunque continuamente me he cuestionado por la poca motivación de mis estudiantes, el peso académico y el cumplimiento de metas me absorben, impidiendo hacer un verdadero cambio al interior de mi práctica docente. De ahí que este trabajo de grado se ha constituido en el instrumento que me permite obtener la validez conceptual y teórica del valor que tiene el que estos jóvenes reconozcan su realidad, que produzcan conocimiento fundado en ella y que se geste un pensamiento critico, transformador. Gracias a los estudios en filosofía latinoamericana y al abordaje de pensadores como Orlando Fals Borda, James Mckernan y Donald Shön principalmente encuentro que esto es posible.

A continuación, presentaré la puesta en marcha del SEMILLERO INTUS LEGERE, como propuesta alternativa para el estudio de esa realidad, para la producción de conocimiento desde ese saber popular, de ese sentido común y de la confrontación de saberes. En este apartado se mencionan los fines del semillero de investigación, la definición de semillero utilizada, el objeto de indagación, los principios que lo rigieron apoyándonos en los autores mencionados en el capítulo uno, pero también apoyándonos en el estado del arte que se realizó acerca de los semilleros de investigación.

\section{El semillero de investigación Intus Legere}

El semillero INTUS LEGERE (Escoger entre...) se creó en julio de 2015 en la institución educativa CODEMA IED, con un promedio de 30 participantes cuyo fin fue constituirse en un 
espacio de reflexión, observación y análisis de la realidad con miras a la construcción de conocimiento colectivo, siguiendo el lineamiento de Fals Borda para quien «El conocimiento es el resultado de la confrontación dialéctica de explicaciones o "saberes" conformadores de las líneas de pensamiento con la realidad local, regional o universal; los cuales pueden ser formulados en forma de teorías, modelos o enunciados» (Fals Borda, 2013).

El semillero Intus Legere adopta el concepto de resistencia, como un ejercicio que permite develar la opresión, y así reconocerla para lograr establecer mecanismos de ordenamiento que lleven a una transformación de sus realidades. Existe una clara distinción entre la adopción de posturas de oposición y actos de resistencia; la primera simplemente conduce a acciones de tipo irreverente que usualmente corresponden a intereses individualistas; mientras que la resistencia obedece a un ejercicio que se da entre sujetos conscientes de la necesidad de cambiar el orden establecido a través de actos que desestabilizan el statu quo e intentan transformar la realidad en algo mejor.

El semillero conformado con los y las estudiantes del Colegio CODEMA IED tuvo en cuenta lo planteado por las autoras Piedad Ortega, Diana Peñuela y Diana López en su libro Sujetos y prácticas pedagógicas críticas (1999, p.39) en lo que respecta a las variables que definen sus actos de resistencia:

1. Constitución de colectivos: en el sentido en que los grupos humanos se organizan para desestabilizar el orden impuesto.

2. Enfrentar el poder establecido: con acciones que desestabilicen no solamente espacios pequeños o aislados, sino que intentan afectar de manera significativa la vida escolar, personal y de su comunidad. Para ello es fundamental el reconocimiento de sus realidades.

3. Proponer otras formas de organización: ubicando maneras de estructurarse colectivamente.

4. Soñar otro mundo mejor: es decir la finalidad es cambiar lo establecido por algo completamente distinto. 
5. Tener como objetivo la transformación de la realidad existente: un cambio radical no de reforma sino de transformación

Los y las jóvenes del colegio CODEMA IED aun cuando buscan espacios de resistencia lo hacen muy al margen de la simple irreverencia, intentan organizarse, pero el nivel de participación es mínimo así como su constancia. Estos jóvenes no se proyectan como colectividad y por lo tanto sus aspiraciones tienden a ser impulsos que no logran consolidar. De ahí que se requieran escenarios que los convoquen y les apoyen en la construcción de argumentos que validen sus ideas.

Guiados por este diagnóstico, entendemos por semillero de investigación una estrategia metodológica que tiene como objetivo la formación en investigación sobre un tema o temas elegidos por un colectivo adscrito a este de manera voluntaria que pueden configurarse como escenarios de resistencia y/o de transformación. El semillero se ha constituido como un espacio democrático, que estimula la participación creativa de los y las estudiantes en la búsqueda de nuevos conocimientos y que asume la investigación como herramienta pedagógica y de sustento de la autonomía académica.

Uniendo las ideas antes expuestas y mi proceso de formación en la Maestría en filosofía Latinoamericana, decidí que el semillero fuera un semillero en filosofía latinoamericana. Por tal razón este escenario de resistencia, así como la mayor parte de las propuestas de una filosofía latinoamericana, busca abrir caminos de liberación y que a toda costa promueva acciones en contra de la discriminación y de la exclusión. Es una oportunidad para la denuncia ante las desigualdades, y para la construcción de un ser latinoamericano consciente, responsable y comprometido en la lucha por construir modos de vida justos, equitativos y solidarios.

Lograr que el semillero sea considerado como una filosofía de la praxis, a partir de la cual se interrogue, se problematice el lenguaje, la práctica misma, el poder, el conocimiento, la cultura, la realidad y se señale a estos como elementos constitutivos de la subjetividad y de los procesos de socialización política de cada uno de sus actores es una de las finalidades de este ejercicio de resistencia. Asumir los semilleros de investigación como espacios de resistencia, proporcionan al desarrollo de la investigación una postura crítica y diferente de la concepción de semillero, aportando elementos valiosos para el abordaje de la filosofía latinoamericana como objetivo de estudio del semillero conformado con los y las estudiantes de secundaria del grado décimo y once. 
El valor que representan los grados décimos y once del colegio CODEMA IED, para el desarrollo de la propuesta se fundamentan en dos sentidos: inicialmente porque toda mi experiencia la he recorrido como docente de filosofía y para esta institución particularmente la filosofía solo se dicta en décimo y once. En segunda instancia porque estos jóvenes y jovencitas se encuentran en una etapa del desarrollo en la que la configuración de su criterio y su personalidad se están consolidando.

Ahora bien ¿por qué el pensamiento latinoamericano es el soporte y el objeto de reflexión que guía el semillero y brinda las luces en el reconocimiento de las realidades de estos jóvenes y en la construcción de su pensamiento critico?

El estudio del pensamiento latinoamericano posibilita a los estudiantes un encuentro con sus raíces históricas profundas, pero inacabadas, cambiantes a través del tiempo y que son objeto de reflexión y critica de la actualidad, su estudio es una construcción colectiva e incluyente, que reivindica, concientiza, integra y propone. Parto de la convicción de que a partir de ese reconocimiento haya una toma de conciencia de la necesidad de asumir posturas activas y participativas en su realidad, en su mundo, que busca la transformación de la misma como medio de escape al conformismo y que el libre pensamiento le brindara las bases para la construcción de un conocimiento liberador.

Comenzar a dar cuenta de las verdaderas necesidades de nuestro contexto, de nuestras realidades, no significa desconocer los aportes que desde otros hemisferios nos han hecho. No podemos llegar a una verdadera transformación si seguimos copiando los esquemas de otros contextos. No se trata de aislarnos del mundo intelectual externo sino potenciar la interacción de la sociedad con el medio social y natural, con el conocimiento de nuestra historia, nuestros recursos llevando al fortalecimiento de nuestra identidad cultural como generadora de solidaridad entre todos. (Fals, 2013, p.202).

El semillero busca que sus participantes estén atentos a identificar cuándo las racionalidades propias del orden político imperante permean la lectura de nuestra realidad, permean nuestro discurso, nuestras prácticas y decisiones, bloqueando e impidiendo la generación de pensamientos y procesos emancipadores. Urge reconocer y reflexionar sobre las nuevas racionalidades construidas, desde subjetividades diferentes que gracias al modelo de investigación alternativa 
como la Investigación Acción Participación posibilitan el rescate de nuevos horizontes epistémicos culturales y éticos.

Este desafío implica, reconocer que formarnos a partir de estas racionalidades y subjetividades alternas no debe limitarnos a la simple obtención y transmisión de información o contenidos aun, cuando sean críticos. «Debemos propender por el reconocimiento de los saberes y disposiciones previos, de los sistemas de creencias que todos tenemos, de esta manera generar una real curiosidad epistémica, fundada en la capacidad de asombro, disposición, voluntad de querer pensar desde una perspectiva crítica» (Freire, 2001, p.50).

El acercamiento de los y las estudiantes al pensamiento latinoamericano se constituye en una herramienta fundamental en el proceso de comprensión, búsqueda de sentido, identificación de intencionalidades y establecimiento de consecuencias de nuestra cultura para nuestra vida misma, así como en la toma de posición, de definición y de subjetividades frente a ella.

Para cerrar este apartado me referiré a los principios o reglas que seguí en el semillero para alcanzar el fin propuesto.

Peter McLaren en un apartado de su libro La escuela como un performance ritual: Hacia una economía política de los símbolos y gestos educativos afirma que:

Lo que nos hace falta es una crítica que devuelva su alteridad a aquellas voces que fueron y son marginadas y despojadas de poder por los discursos dominantes (...) Nos hace falta hallar los caminos para incidir en las formaciones culturales y políticas dominantes, de modo tal que podamos prestar atención a la diferencia pero que a la vez compartimos un “ethos común” de solidaridad, lucha y liberación. (1996, p. 72).

El semillero de investigación en filosofía latinoamericana acepta la diferencia, así como aquello que nos une para promover la solidaridad. Será un espacio de resistencia, indignación, afirmación y compromiso de maestros, investigadores, estudiantes que posibiliten la construcción de un vínculo social que va más allá de las diferencias y las desigualdades y que nos unifica como latinoamericanos que somos. Así como una praxis que promueva el sentido de pertenencia, la construcción de comunidades en favor de una verdadera justicia social. 
El segundo principio es que en el semillero se debe promover la sensibilidad frente al reconocimiento de la realidad y de las necesidades de los participantes: «necesitamos, construir paradigmas endógenos enraizados en nuestras propias circunstancias que reflejen la compleja realidad que tenemos y vivimos» (Fals, 2013, p. 202). De ahí que las necesidades, intereses y motivaciones de nuestros estudiantes constituyeron el punto de partida para orientar una práctica pedagógica emancipadora.

El tercer principio es que el semillero debe ser un espacio democrático, significa que supone una confianza real en quienes participan y que el sentido de igualdad impera sustancialmente, es un punto de partida y de llegada, donde todos aportan desde sus diferencias. De ahí la necesidad de que estos jóvenes y jovencitas comprendan el verdadero ejercicio democrático para que su participación sea más activa en sus comunidades y contribuyan a fortalecer su accionar político.

La intencionalidad transformadora del semillero se hace evidente al pretender a través del estudio y análisis de la filosofía latinoamericana lograr que los y las estudiantes sean capaces de construir en colectivo su propia historia, se trata en palabras de Paulo Freire (2001): de desarrollar la capacidad de leer la realidad, decir la propia palabra y escribir la historia de la liberación personal y comunitaria. Fomentar la solidaridad y la ciudadanía responsable, que los participantes sean capaces de imaginar un modelo de sociedad diferente y que su compromiso y participación sean legítimos (p.52).

El semillero de investigación en filosofía latinoamericana pretende una tarea humanizadora, es evidente la necesidad de contribuir en la construcción de seres humanos con altos grados de empatía social que no sean conformistas y obedientes, sino que sean partícipes de una verdadera libertad de pensamiento y de expresión, comprometidos con el bien común. Busca provocar las ganas de vivir con sentido y con proyección conscientes de su realidad y de su papel protagónico en la transformación de la misma. No puede ser suficiente aprender a pensar, expresarnos, leer y comprender la realidad, el objetivo del semillero es brindar su transformación y esto solo se puede llevar a cabo si nos reconocemos como latinoamericanos, si indagamos en nuestro pasado para comprenderlo y encaminarlo hacia lo que queremos ser.

En síntesis, cuatro son los principios que deben regir el semillero: la aceptación de la diferencia y la promoción de la solidaridad, el reconocimiento y escucha de las necesidades y 
opiniones de los participantes, la promoción de actitudes democráticas y la búsqueda del bien común.

Asumir el semillero como espacio social donde se busca recuperar los saberes que guardan en la memoria nuestros estudiantes, una memoria de conflictos y de resistencias, de heridas, de olvidos, de exclusiones, memoria de sus procesos de constitución como sujetos; nos hace obligatorio el recurrir a la manera como se construyen las identidades de estos jóvenes, la cual se forma en el patio, en la acera, en las esquinas de sus barrios, en el aula. En ese encuentro con el "otro". Por lo que el semillero se conforma desde un proceso de negociación cultural que a partir de la confianza que no borra su historia, sino que posibilita «nuevas redes de interacciones, la incorporación de discursos y significantes que les permiten reconstituirse como sujetos reconocidos en sus espacios vitales» (Piedad Ortega, Diana Peñuela y Diana M. López, 2009, p. 103).

La percepción y observación de la realidad circundante de estos jóvenes y la aplicación de reglas de inferencia lógica para su análisis con miras a generar un cambio en las ideas y en la visión personal que tenga cada uno de ellos y ellas fue fundamental para el semillero. No se trata de la simple acumulación de conocimiento, se pretende que esa comprensión de su realidad les permita obtener una postura intelectual autónoma. Combinar el rigor científico con la participación de estos jóvenes en el reconocimiento del proceso histórico en el que se encuentran fue un paso decisivo para lograr una transformación en el imaginario que se tiene de la ciencia, del conocimiento, de mi práctica pedagógica y de la vida misma.

La participación es de gran importancia, entendida esta como el rompimiento de la relación de dependencia y sumisión que se ha dado de manera histórica y tradicional entre un sujeto y un objeto. Al permitir que los y las estudiantes puedan expresar sus opiniones sin que estas deban estar validadas por una "comunidad académica" ha hecho que su idea de aprender se transforme afirmando que en su proceso educativo lo que han logrado es memorizar información que otros han hecho y que ellos presumen como válida y verdadera pero que es desde el mismo dialogo de saberes que se construye el conocimiento. Esto ha sido de vital importancia para sus participantes, y aun continuamos abordando esta nueva manera de conocer y generar conocimiento.

El enfoque de la IAP marcó el rumbo del Semillero de Investigación, su orientación teórica constituye el eje central de la presente investigación. La premisa dos esta enfáticamente signada 
por la idea de que el semillero se constituya como un espacio de reflexión, observación y análisis de la realidad con miras a la construcción de conocimiento. Y seguir el lineamiento de Fals Borda para quien "El conocimiento es el resultado de la confrontación dialéctica de explicaciones o "saberes" conformadores de las líneas de pensamiento con la realidad local, regional o universal; los cuales pueden ser formulados en forma de teorías, modelos o enunciados” (Fals Borda,2013).

El semillero de investigación conformado por los y las estudiantes de grado décimo y once del colegio CODEMA IED, ha venido estableciendo las bases para que la construcción del conocimiento se desarrolle desde el descubrimiento, la exploración y el reconocimiento de otras perspectivas de solución a los problemas y preguntas de su entorno, haciendo que los y las estudiantes argumenten y den paso a la transformación de sus realidades.

Que abre la posibilidad de leer el contexto inmediato para transformarlos, buscando empoderar al sujeto, tomándolo no cómo un ser pasivo sino activo, dándole la posibilidad de disentir sobre la visión oficial del mundo, a la vez que propende por animar a la reflexión sobre lo que se hace, quienes son las personas que se silencian, a quienes se les da la palabra, cual es el significado del conocimiento producido (Marimón., 2009).

El Semillero pretende «construir paradigmas endógenos enraizados en nuestras propias circunstancias que reflejen la compleja realidad que tenemos y vivimos» (Fals Borda, 2013, p. 202). De ahí que las necesidades, intereses y motivaciones de nuestros estudiantes constituyen el punto de partida para orientar una práctica pedagógica emancipadora.

Comenzar a dar cuenta de las verdaderas necesidades de nuestro contexto, de nuestras realidades, no significa desconocer los aportes que desde otros hemisferios nos han hecho. No podemos llegar a una verdadera transformación si seguimos copiando los esquemas de otros contextos. No se trata de aislarnos del mundo intelectual externo sino potenciar la interacción de la sociedad con el medio social y natural, con el conocimiento de nuestra historia, nuestros recursos llevando al fortalecimiento de nuestra identidad cultural como generadora de solidaridad entre todos. (Fals Borda, 2013, p 198).

El semillero busca que sus participantes estén atentos a identificar cuándo las racionalidades propias del orden político imperante permean la lectura de nuestra realidad, permean nuestro discurso, nuestras prácticas y decisiones, bloqueando e impidiendo la generación de pensamientos 
y procesos emancipadores. Urge reconocer y reflexionar sobre las nuevas racionalidades construidas, desde subjetividades diferentes que gracias al modelo de investigación alternativa como la Investigación Acción Participación posibilitan el rescate de nuevos horizontes epistémicos culturales y éticos.

Los participantes hemos venido haciendo uso de la investigación Acción participativa como modelo de investigación (procedimientos específicos). Su aporte estructural esta dado en el valor que le confiere a la praxis, a las acciones que conducen a un cambio y sobre todo a la comunidad como fuente primordial en la construcción de conocimiento, cuya metodología es integrante, la cual busca no solo ser un método de investigación, sino también llegar a los grupos sociales desde la acción política:

La IAP es una metodología de vida y de trabajo productivos que exige la combinación de diferentes perspectivas sobre la ciencia y la acción política que trata de acomodarlas para llegar a determinadas metas y producir efectos de transformación de la sociedad (Fals Borda, 2013, p.207).

La IAP es la metodología que permite ese reconocimiento de las bases sociales y expresa su aprecio valorativo hacia el saber popular como fuente primordial en la construcción del conocimiento identificando en ella una racionalidad y estructura propia.

Para estos jóvenes es un cambio en su idea de lo que significa aprender y lo que significa construir conocimiento, ellos consideraban que para hacer conocimiento se debía ser un científico, o un personaje de la historia (términos empleados por ellos), solo creían que se lograban nuevas teorías, si se empleaba el método científico. Este ha sido un gran paso, ya que el poder concebir que sus ideas tengan validez y que junto con otras se genere el conocimiento ha sido tal vez uno de los mayores logros al interior del semillero.

"Existe otra racionalidad tan científica como esta y es la racionalidad de lo cotidiano" (Fals Borda, 1986, p.211). Es en este aspecto en el que se sustenta el horizonte del semillero ya que permite que desde las propias vivencias y experiencias que tienen los y las jóvenes al interior de su contexto se pueda propiciar un acercamiento a estas racionalidades cotidianas. 
La IAP intenta acercar estas dos corrientes, ya que su separación conduciría a la destrucción de la vida misma; es necesario recobrar la emocionalidad, el sentimiento y rescatar lo humano de la ciencia misma. «Cuando olvidamos nuestros orígenes y volvemos a la ciencia un fetiche, nos convertimos en un peligro para la humanidad» (Fals Borda, 1986, p. 212).

El semillero de investigación ha combinado esta participación con lecturas y documentación de textos y de reflexión sobre las ciencias. Los y las estudiantes han establecido un comité al que llaman "Comité documental” y es el encargado sobre la base de una temática puntual de ir haciendo un registro de los documentos abordados para consulta de quienes más adelante deseen hacerlo.

El semillero promueve como ya se dijo, que los estudiantes participen no sólo como agentes pasivos sino como agentes activos que diseñan las sesiones, las ejecutan y las evalúan. A reflexionar sobre las múltiples formas de negar la voz y los sentidos del mundo y que en la historia del país se observa aun la conservación de las estructuras hegemónicas y de dominación bajo el precepto euro centrista. Decimos que el semillero se configura como un espacio de resistencia, un lugar de emancipación donde se promueve el pensamiento crítico fronterizo.

La creación de comités por enfoques social, político, económico, cultural entre otros ha logrado que los y las estudiantes en sus procesos de discusión y construcción de conocimiento y de resolución a una problemática en particular, promuevan un sentido crítico ante su realidad reconociendo las diversas formas de tratarse una situación, una pregunta o una aseveración. Esta manera de abordarlas les permite a través de sus propias reflexiones construir una idea propia y argumentada.

Por otro lado tener como eje la generación de una sensibilidad ante la realidad, ha constituido un reto, se han realizado sesiones en las que ellos y ellas plantean problemáticas comunes, tratando de desarrollarlas bajo distintas ópticas por ejemplo si el problema de la venta de bazuco de la esquina del barrio es responsabilidad de la policía, del Gobierno, de la Junta de Acción comunal, de la gente de la cuadra, del barrio o de los jóvenes que van allí a comprarla. Esta manera de abordar algunas problemáticas ha logrado calar en ellos una actitud menos prejuiciosa y condicionada. Son este tipo de sesiones que los lleva a subvertir el orden establecido y la manera de abordar un problema. 


\section{Pautas metodológicas}

Las pautas metodológicas están constituidas por los parámetros que guiaron el diseño de las sesiones del semillero, la sistematización de las actividades del semillero, así como el desarrollo del trabajo de grado. Es decir que a partir de estos parámetros definí las fases, pasos y procesos de estos tres ámbitos teniendo en cuenta que debía organizarlos hacerles seguimiento y evaluarlos. Estas pautas metodológicas se construyeron teniendo en cuenta las recomendaciones de la Investigación acción participante, las pautas de la Investigación acción y algunas técnicas de la sistematización de experiencias, las cuales se describen en el capitulo 3.

El desarrollo metodológico de esta propuesta está constituido inicialmente por un diagnóstico, el cual da cuenta de como se estructuraron las sesiones, tiempos, además de las características generales de sus participantes. Luego el diseño del proyecto de aula el cual hace referencia a las sesiones que se llevaron a cabo en el semillero, su descripción y en general todos los relatos obtenidos de su proceso y por último el análisis y evaluación de esta experiencia, la cual se hace a través de la sistematización de la misma. Aspectos que serán descritos con mayor detalle en el capítulo 3. 


\section{Capítulo 3}

\section{Desarrollo metodológico de la propuesta y sistematización}

Este capítulo se desarrollará atendiendo a las pautas metodológicas descritas en el capítulo dos así: 1. Diagnóstico y descripción del semillero, 2. Análisis y sistematización y 3. Evaluación del semillero.

\section{Diagnóstico y Descripción del Semillero}

El semillero de investigación se constituye en julio de 2015, el cual surge por iniciativa de algunos jóvenes interesados en crear espacios de debate generados desde las clases de filosofía pero que por tiempo se hacía complejo. Como docente busqué el espacio con las directivas de la Institución, quienes fueron un apoyo importante pero que debido a que la institución maneja dos jornadas los espacios estaban restringidos, sin embargo, hubo colaboración en la medida de lo posible. Inicialmente hicieron parte del semillero treinta jóvenes de los grados décimo y once. Hubo que solicitar permiso a sus familias para que se pudieran quedar después del horario de clases, y llegar a acuerdos para que este proceso no entorpeciera su rendimiento académico ya que esta era la mayor preocupación de las familias. Este también fue un ejercicio que se hizo con las familias tratando de sensibilizarlos un poco sobre el valor que este semillero representaba para sus hijos e hijas. Tarea que fue bastante compleja ya que para muchos de ellos era una pérdida de tiempo, incluso referían que por qué no mejor un semillero en matemáticas o ciencias. De igual manera los tiempos con los que contábamos no podían ser superiores a una hora u hora y media máximo, debido a que ellos y ellas prefirieron quedarse de una vez después de la jornada puesto que si se regresaban a sus casas muy seguramente ya no los dejarían volver.

Aun con estas dificultades nos organizamos y establecimos horarios que después tuvieron que hacerse flexibles ya que también los espacios no eran fijos y debíamos estar cambiando de acuerdo a los requerimientos de la institución. 
Junto con el grupo de estudiantes estructuramos el semillero. De manera colectiva establecimos la justificación del porqué era necesario este espacio, definimos lo que esperábamos del semillero (objetivos), convenimos sobre cuáles eran las características de quienes se consideraban miembros, además configuramos una línea de investigación y decidimos cuáles serían las actividades generales que se desarrollarían a su interior. Por otro lado acordamos que debían existir unos productos propios del ejercicio de deliberación y debate. Posteriormente le dimos un nombre: Intus legere que significa "escoger entre", ya que para muchos eso significaba reunirse: escoger entre...

Decidimos que se nombraría una persona en cada sesión para que llevara el registro de lo que se hacía en un acta, también vimos la necesidad de construir un reglamento interno para que todos tuviéramos claro las reglas sobre las cuales se erigía el semillero. Por otro lado, y con el paso de los encuentros los y las jóvenes se fueron organizando en Comités de acuerdo a las necesidades que se presentaban. Todos acordamos darle un carácter de rigurosidad para que realmente sus integrantes nos sintiéramos parte de un colectivo de investigación.

Con el paso del tiempo los estudiantes de grado once que fueron egresando de la institución y que hacían parte del semillero, en su mayoría se fueron retirando del mismo, o asistían de manera ocasional. Algunos de ellos ingresaron a las universidades y otros iniciaron una vida laboral. Esto lamentablemente hizo que la continuidad del semillero se viera afectada.

Los y las participantes hacemos un gran esfuerzo para convocar a los y las estudiantes de la institución, sin embargo, muchos de ellos y ellas en particular este año debido a que tienen que asistir a clases en la tarde se han retirado del semillero o asisten muy pocas veces. No obstante, seguimos trabajando y estamos abiertos a recibir a todos los que deseen hacer parte. El semillero en este momento cuenta con doce participantes activos.

\section{Descripción de los encuentros}

Los primeros encuentros se dedicaron exclusivamente a la organización y estructuración del semillero, a buscar un nombre y establecer las "reglas de juego" (Afirmación de Ginna Fonseca, Bryan Herrera y Laura Gil, en el encuentro de Julio 16 de 2016), proceso que fue muy importante 
ya que fue de ellos de quien surgió la necesidad de establecer las normas, allí se generó un debate muy interesante en torno al porqué esa necesidad del ser humano de las normas y las reglas. Algunos de ellos afirmaban "que este era un espacio libre y que no se debía tener reglas" "que la voluntad y las ganas eran suficientes" (afirmación de Leidy Pineda y Heidi Cuervo, encuentro de julio 6 de 2015) y que "esto debía ser un espacio de autonomía" (Afirmaciones de: Oscar Becerra y Johan Linares. Encuentro de julio 16 de 2015) a lo cual sus pares respondieron: "Necesitamos unos mínimos para que esto no se vuelva un desorden, porque entonces si es de libre albedrío todos llegan a la hora que quieran y si quieren participan o no o no hacen las tareas que queden asignadas" (Afirmaciones de: Mariana Pérez, Ginna Fonseca, Bryan Herrera y Laura Gil. Encuentro de julio 16 de 2015 y agosto 6 de 2015). Este debate sirvió para que todos buscaran mayores argumentos en sus opiniones encontrando en conceptos como: autonomía, albedrío y anarquía y en general en todos aquellos que le dieran sustento a sus argumentos un soporte para la toma de una decisión fundamental para el semillero: asumir o no una normatividad. Este espacio de construcción democrática ha permitido que los y las estudiantes expongan sus puntos de vista y que cada situación sea una oportunidad para la construcción de conocimiento colectivo y propio.

Finalmente, sus participantes llegaron al acuerdo de establecer unas normas mínimas para que éste pudiera funcionar, decidieron que fueran sólo tres y más en torno a las responsabilidades de quienes venían al semillero, del coordinador y en general del proceso de inscripción. Este último fue muy interesante porque en conjunto decidieron que había que darle una rigurosidad y una imagen al colectivo. Plantearon que hubiese carnetización e incluso hacer un membrete para sus propuestas y algunos plantearon que "debían tener un distintivo ya fuese una camiseta o algo que los diferenciara del resto" (Afirmación de: Leonardo Mendoza. Encuentro de agosto 20 de 2015). La necesidad de generar adhesión e identidad fue fundamental, se evidenció el entusiasmo y la fuerza que este último tuvo para todos sus participantes. Característica propia de estas edades.

La selección del nombre también fue un proceso muy interesante, uno de los estudiantes propuso: "United for the cause" (Andrés Felipe Ballesteros. Encuentro Agosto 6 de 2015), en inglés; y algunos entusiasmados se unieron a este nombre, hasta que la participante Derly Gómez propuso: "Intus Legere", intervención que fue crucial para aterrizar a sus compañeros y compañeras en el sentido del Semillero: "Estamos reunidos aquí para hacer parte de un semillero de investigación en filosofía latinoamericana y ¿queremos ponerle un nombre en inglés?, no creen que 
esto es absurdo, entonces realmente ¿para qué nos reunimos? si luego nuestro ideal no es reconocer nuestras raíces y lo que somos realmente y no seguir trayendo de otros lados términos y nombres por sentirnos no sé, ¿superiores o mejores o más interesantes? ¡Compañeros que nos pasa! Me puse a buscar palabras en nuestras lenguas indígenas para que realmente el semillero desde su nombre diera cuenta de lo que es y ustedes quieren ponerlo en inglés, entonces creo que no vamos por buen camino" (Encuentro de agosto 6 de 2015). Los y las participantes se quedaron callados por unos minutos y luego comenzaron a hablar entre ellos. Hasta que Carlos Arias tomo la vocería y dijo: “sí que pena tiene razón Derly, es que estamos muy mal influenciados, y gracias por hacernos caer en cuenta, creo que el voto es unánime y decidimos que sea el que usted propuso, nos gusta y si tiene que ver con todo... porque al fin y al cabo de esto se trata de "escoger entre" lo que nos impulsa a ser lo que somos" (Encuentro de agosto 6 de 2015). Este encuentro fue muy emotivo, se marcó el rumbo del semillero, aun cuando se había descrito en un documento su propósito se evidenciaba que no estaba del todo interiorizado por sus participantes, y con este evento hizo que se internalizara realmente. Nos llevó a asumir el semillero de investigación como un espacio de resistencia, que proporciona al desarrollo de la investigación una postura crítica, aportando elementos valiosos para el abordaje de la filosofía latinoamericana como objetivo de estudio del semillero conformado con los y las participantes.

Hemos venido logrando que el semillero sea considerado como una filosofía de la praxis, a partir de la cual se interroga, se problematiza el lenguaje, la práctica misma, el poder, el conocimiento, la cultura, la realidad y considerando a estos como elementos fundamentales de la subjetividad y de los procesos de socialización política de cada uno de sus actores siendo una de las finalidades de este ejercicio de resistencia.

Otro de los grandes debates que se llevaron a cabo en los primeros encuentros tuvo que ver con la idea de investigar. Se presentaron discusiones en torno a que ellos incluso no podían investigar que "eso era para gente estudiada, especializada" (Afirmación de Aura María Novoa. Encuentro septiembre 3 de 2015), o que "eso solo se hace en un laboratorio" (Afirmación de Ginna Fonseca. Encuentro septiembre 3 de 2015). Se estableció la diferencia entre indagar e investigar. En su mayoría asumían la investigación como la aplicación única del método científico, y que no existían otras posibilidades. Incluso muchos de ellos manifestaron que si era así mejor se retiraban, porque lo que querían era: "que escuchen lo que opinamos, que discutamos, que aprendamos, pero 
sin tener que hacer informes sobre lo que otros hicieron o piensan" (Afirmación de Harold Gonzáles y de otros que lo apoyaron como: Jonathan Zamora, Javier Ruiz, María Paula Ramírez. Encuentro septiembre 3 de 2015). "Que ellos lo que querían era filosofar" (María Fernanda Ovalle. Encuentro Septiembre 3 de 2015) Era evidente que la idea de investigar estaba mal enfocada y que debíamos iniciar dando un verdadero sentido a esa construcción de conocimiento colectivo así como también a tratar de comprender cuál era esa idea de filosofo o filosofa (si existía para ellos) tenían los y las participantes.

En los siguientes encuentros nos dimos a la tarea de comprender cuál era su idea de ser filósofo y que era filosofar, además de comprender si existía o no diferencia entre filosofar e investigar. Ejercicio que fue muy oportuno ya que además tuvimos la oportunidad de asistir al Encuentro con los docentes de la Maestría en Filosofía Latinoamericana de la Universidad Santo Tomás. En este evento nos acompañó la Dra. Ángela Niño, la Maestra Claudia Giraldo y el profesor Juan Cepeda, además que algunos jóvenes estudiantes de pregrado pudieron compartir su experiencia a cerca de estudiar Filosofía.

Este encuentro suscitó en los y las participantes innumerables inquietudes, salieron del evento con muchas incógnitas, ideas y muy animados a estudiar una carrera como la Filosofía. Fue curioso escucharlos decir: "Uy yo creía que los filósofos debían ser muy viejos" (Afirmación de María Paula Novoa y Derly Gómez. Día del Evento 23 de Septiembre 2015) o "no sabíamos que existían mujeres que estudiaran filosofía" (Afirmación de Jonathan del Toro. Día del Evento 23 de Septiembre 2015) "pensé que ser filósofo era alguien que no prestaba mucha atención a los demás sino que solo se elevaba por toda su sabiduría" (Afirmación de Katherine Acero. Día del Evento 23 de Septiembre de 2015) "nunca pensé que tuvieran familia" (Afirmación de Laura Molano. Día del Evento 23 de Septiembre de 2015), "yo creía que era algo muy aburrido y que no se les iba a entender nada" (Afirmación de Heidi Cuervo. Día del Evento 23 de Septiembre de 2015) "pensaba que era muy diferente ser filósofo a ser profesor de filosofía" (Afirmación de Claudia Forero. Día del Evento 23 de Septiembre de 2015). Todas estas afirmaciones dieron cuenta de lo que para los y las jóvenes era ser filósofo, o filosofar. Se confrontaron y en los siguientes encuentros nos dimos a la tarea de buscar por ejemplo mujeres filosofas en la historia, de buscar fechas de nacimiento y muerte de diversos personajes de la filosofía para establecer sus edades; se hizo una breve encuesta a algunos de los y las compañeras de clase sobre qué edad creían debía tener una persona para ser 
filosofo o si creían que existían mujeres filosofas. Estas propuestas surgieron para corroborar las ideas que ellos tenían y para no sentir que eran solo ellos los que pensaban eso.

Este ejercicio de igual manera y junto con lecturas que ellos traían sobre investigar, investigar en filosofía, modelos de investigación y demás fueron consolidando su idea de investigar y filosofar.

A partir de ello se consolidó en los y las participantes una idea muy importante y era el hacer un preguntario, "siendo la pregunta la base para filosofar e investigar" (Afirmación de Derly Gómez. Encuentro 1 de Octubre de 2015). Propuesta que fue acogida por el grupo y que decidieron dedicarle a su organización un encuentro en particular. Allí establecieron que todos siempre debían depositar una pregunta que quisieran abordar, inicialmente debatieron si debía ser sobre cualquier tema o si estos debían ser solo con relación a los objetivos del semillero. Para ello decidieron que se harían dos urnas, una que se manejaría para que fuese sobre cualquier temática y otra que estuviese ligada al objetivo del semillero, que dedicarían los primeros quince minutos del semillero a resolverlas o debatirlas.

Los y las participantes comenzamos a dar cuenta de la necesidad de organizarnos ya fuera por temas o comités debido al cumulo de preguntas que se generaban, además porque empezamos a enviar ponencias para participar en Foros de filosofía. Por lo que se decidió que fuera en comités, los cuales permitieron clasificar las preguntas de acuerdo a su intencionalidad y así de esa manera poder conformar grupos especializados en aquellas preguntas que fuesen seleccionadas por un comité directivo para que se trabajaran a profundidad. Los y las estudiantes paulatinamente fueron estableciendo las pautas de trabajo que de acuerdo a sus intereses requerían para el funcionamiento del semillero.

Una de las preguntas que más interés suscitaba en los y las participantes era sobre “¿Sí hacer parte de un semillero para que les serviría en la vida real?” (Pregunta de Fernanda Céspedes y Geraldine Salazar. Encuentro de Noviembre 16 de 2015), o también lo planteaban como “¿Se puede vivir de la filosofía? (Pregunta de Tatiana Vargas. Encuentro de Noviembre 16 de 2015), otra de las preguntas a la que referían muchos los y las participantes era ¿esta es la vida que nos toca vivir, la filosofía me puede ayudar a cambiar esta vida? ¿ mi realidad es la misma que la de mis compañeros? (Pregunta de Christian Otalora. Encuentro de Noviembre 16 de 2015). Todas 
estas preguntas se condensaron en dos aspectos fundamentales: la realidad, estudiar la realidad y estudiarla para que... Estos fueron los ejes sobre los cuales el Semillero para el año siguiente esperaba trabajar.

El año 2016 inició un poco confuso, muchos de los y las estudiantes de los grados once del colegio ya no estaban, y los que pasaron a once y que venían haciendo parte del semillero se retiraron debido a la presión familiar de que este era su último año y que debían dedicarse exclusivamente a pasarlo. Quedaron muy pocos estudiantes así que nos dimos a la tarea nuevamente de hacer una gran convocatoria para que estudiantes de décimo y once se unieran nuevamente. Fue interesante ver como los y las participantes que ingresaban se acogían a las normas que los otros habían establecido e incluso exigían muchas otras. Algunos de ellos lo hacían porque sus compañeros lo hicieron más no por un interés personal. Por otro lado, hubo la necesidad de convenir nuevos espacios y tiempos para ello. Igualmente realizar el procedimiento para que las familias tuviesen el conocimiento de la existencia de este semillero. El grupo con el que se inició fue muy pequeño, pero poco a poco se fue consolidando, además de ver como los y las jóvenes que ya eran egresados asistían ocasionalmente haciendo que su interés permeara a todos.

Se acordó que solo sería una reunión mensual de dos horas y que estas fuesen a la una de la tarde dejando espacio para que los y las participantes pudieran almorzar. Este nuevo grupo decidió que no debían quedar tareas adicionales, sino que todo se trabajaría en ese tiempo y espacio. Algo con lo que antes se contaba pero que de igual manera se comprendió debido a la cantidad de trabajos que se estaban dejando en sus clases.

Así es que hasta el mes de Marzo se pudo dar inicio al primer encuentro del semillero Intus legere. Se hizo una breve exposición sobre los acuerdos, y lo realizado en el 2015, además de dar cuenta de lo que se iba a abordar para este año. Temáticas que fueron muy bien recibidas por todos los y las participantes.

Los y las participantes propusieron realizar unas encuestas y entrevistas a todos los demás compañeros de los grados decimo y once del colegio para tener una idea más clara sobre que percibían ellos sobre lo que es la realidad, sobre si esta se puede cambiar o ya está determinada, si nuestra realidad es igual a la de mis padres, mis maestros, entre otros. Nos reunimos en varias sesiones para establecer a quienes se harían entrevistas y cuáles serían las preguntas que la guiarían, 
las características de una entrevista, entre otras. Así mismo para la encuesta, tratando que esta fuese lo más clara y no muy larga.

Para ello dedicamos varios encuentros a su análisis y descripción. Se encontraron muchas contradicciones sobre la idea de realidad que tienen los y las jóvenes de los grados decimo y once del colegio CODEMA IED. Hay una clara tendencia a pensar que tiene mucho que ver con la verdad, con lo que se puede comprobar, le dan un carácter en su mayoría muy objetivo. Sin embargo, a la hora de preguntar si esta se puede cambiar atribuyen mucho a la personalidad, o a las ganas, o al compromiso la opción de cambio. Explican en su mayoría que la realidad está determinada pero que se puede cambiar solo si quien la vive quiere cambiarla. Es muy interesante ver como a partir de estas encuestas y entrevistas se construyó el concepto de realidad que tienen los y las jóvenes participantes del semillero. El cual abordaremos con mayor profundidad en el apartado dedicado a su análisis y sistematización.

Por otro lado, en los encuentros también se debatió el concepto de identidad, el cual surgió del análisis que se hizo sobre la importancia de reconocer la realidad circundante. Los y las participantes veían que lo mencionaban muchísimo gracias a un ejercicio que hizo un relator quien se encargó de puntualizar sobre las palabras que más decimos cuando hablamos de la realidad. Por ejemplo, fue muy importante cuando el relator dijo que en ese encuentro habíamos repetido la palabra identidad cuarenta y tres veces y que "siempre la dicen cuando se refieren a que sí sabemos sobre cómo es nuestra realidad nos identificaremos más con ella" (Ángela Londoño. Encuentro Junio 20 de 2016).

Otro de los encuentros los y las participantes decidieron que aprovechan el uso de la tecnología sería interesante poder contactar con jóvenes de otros sitios, inicialmente de nuestro país y luego propusieron hacerlo con otros países e indagarlos sobre cómo es la realidad que ellos viven y así poder hacer una comparación y poder de manera más puntual comprender si vivimos diferentes edades. Laura Tatiana Arévalo (Encuentro de Junio 18 de 2016) propuso que debían ser jóvenes que tuvieran el mismo rango de edad que ellos; sin embargo Luis Alfredo Gutiérrez propuso que sería interesante si también se preguntara a personas adultas. Todo el colectivo concretó que se haría inicialmente con jóvenes y que posteriormente cuando ese ejercicio estuviese ya consolidado lo harían con otros rangos de edad. En este ejercicio nos dedicamos los siguientes 
cuatro encuentros, ya que como se había convenido no se podían dejar tareas para fuera.

Los y las participantes se encontraron muy comprometidos con el proceso de búsqueda de jóvenes de otros territorios, y encontraron similitudes en cuanto a sus sueños, sus aspiraciones pero sus realidades si estaban marcadas por eventos propios de sus contextos que hicieran que pensaran diferente. Dieron cuenta de jóvenes marcados por la violencia de nuestro país, encontraron que la idea de pobreza es relativa, y que eso básicamente era un factor muy importante en la realidad y la mirada que cada uno tiene de ella. Hubo muchos comentarios al respecto: "yo pensaba que mi realidad era igual a la de todos los jóvenes de mi país" (Comentario de Alejandra Vanegas. Encuentro Septiembre 12 de 2016), "fue muy triste ver que mientras yo espero poder salir de pobre algún día, tener plata, vivir bien, tener buena ropa, ropa de marca hubo un muchacho que vive en Leticia que me dijo que el solo quería volver a su tierra, a la selva y vivir sin violencia, que sus padres y hermanos se volvieran a reunir" (Comentario de Adelaida López. Encuentro Septiembre 12 de 2016) "Me di cuenta que a los muchachos que yo entrevisté de aquí de Bogotá todos piensan mucho en estudiar, mientras que a uno de Estados Unidos que le pude preguntar dijo que solo quería viajar por el mundo" (Comentario de Alejandro Sarmiento. Encuentro Septiembre 12 de 2016), “mi realidad es muy diferente a la de las niñas que entrevisté de un colegio del norte, ellas no tienen que pensar en pagar su universidad sino en qué van a estudiar, pero algo curioso es que ellas me dijeron que se sentían solas y me preguntaron que si mi mama estaba en la casa y pues si ella como no tiene trabajo siempre esta, y una de ellas dijo que ella nunca la veía. Eso me pareció muy triste" (Comentario de Ángela Borrero. Encuentro Septiembre 12 de 2016). Aquí tuvimos que reflexionar un poco sobre las emociones que estos jóvenes tuvieron en el proceso y poder hacer una descripción un poco más objetiva de las realidades de las personas a las que entrevistaron. Los y las participantes nos organizamos y escogimos dos territorios para hacer una descripción desde lo geográfico, los oficios, las profesiones, los tipos de trabajo de esos sectores, el tipo de vivienda, las necesidades en general, el tipo de educación que reciben, entre otras. Para así poder identificar mejor su contexto. Los tres escenarios fueron: Bogotá sector de Patio Bonito y Bogotá zona norte.

En el encuentro del mes de Octubre después de haber abordado el concepto de realidad, cada participante realizó un breve escrito a cerca de: 1. Cómo es su realidad, 2. Su realidad se puede modificar y cómo lo haría. 3. Para que le sirve a cada uno reconocer e identificar su realidad circundante 4. Si la realidad que cada comunidad tiene afecta o influye en la manera de pensar y 
actuar. Estas preguntas fueron producto de un ejercicio colectivo en el que se consolidaron para que por grupos se dieran a la tarea de hacer un escrito con base en cada una de las preguntas.

En el mes de noviembre no tuvimos encuentros ya que los estudiantes estaban muy al tanto de su año escolar. Por lo que se tuvo que dejar el trabajo para el siguiente año.

Al inicio del 2017 nuevamente nos vimos enfrentados a que algunos de sus participantes eran de grado once y tuvieron que salir del seminario porque ingresaron a estudiar o a trabajar. Sin embargo, quedaron muchos de grado décimo que entusiasmados decidieron continuar. Lamentablemente para este año el colegio se acogió al Media Fortalecida donde los estudiantes de grado décimo y once tomarían clases en las horas de la tarde. Esto ha sido una circunstancia muy difícil, las familias afirman que tienen mucho trabajo y los y las jóvenes aun cuando quieren sus tiempos son limitados. No obstante, hemos decidido tomar algunos espacios de la clase de filosofía para trabajar en el semillero, de ahí que hemos logrado hacer algunos ensayos. Igualmente, el interés existe y el deseo de dar continuidad nos encontramos en este momento buscando esos espacios y tiempos. Sin embargo, todos estos ejercicios los hemos compilados en cuatro relatos en torno a tres aspectos que a juicio de los y las participantes sintetizan el resultado de sus reuniones: De dónde vengo y para donde voy; Prefiero ser latinoamericano que europeo, Mi realidad, tu realidad, nuestra realidad... se pueden transformar y Filosófate la vida.

Como lo afirme en el capítulo dos: El hecho de reconocer y valorar el saber del otro, permitirle su participación como sujeto activo en el proceso de investigación posibilitó una verdadera articulación entre el conocimiento académico y la sabiduría popular, lo racional con lo existencial. Esto significa que el conocimiento se concibe como una construcción social y colectiva. Lo cual se evidencia particularmente en los y las jóvenes que día a día participan de manera activa en el semillero a través de sus experiencias, sus sentires y lo que paulatinamente vamos asimilando sobre otras posturas ideológicas. Hemos construido conocimiento desde lo que somos y desde lo que queremos.

\section{Análisis y Evaluación de la propuesta}

Durante la implementación del semillero hemos evidenciado que los y las participantes han manifestado en sus expresiones un cambio sustancial, generando una mayor sensibilidad con sus 
pares y su contexto en general, en lugar de culpar siempre a los demás por todo cuanto ocurre: estado, policía, justicia, medios de comunicación, religión, etc. Dando cuenta de su participación ya sea por omisión de cualquier problemática que se presenta en su contexto. El reconocimiento de su realidad y situarse él o ella como parte activa del mismo ha sido la ganancia mayor de este proceso.

Aún hay muchos retos, lograr que estos jóvenes y jovencitas a través del semillero se reconozcan desde sus raíces, su cultura, su idiosincrasia es una tarea a la cual seguimos apuntando. Muchos de ellos continúan con expresiones de desarraigo pero que gracias a los debates y al proceso de documentación se ha transformado, no de la manera que se espera, ya que aún muchos de ellos manifiestan comentarios excluyentes propios de la cultura en la que se encuentran inmersos. No obstante, se espera que poco a poco se logren avances en este sentido. De igual manera hemos podido comprender como el semillero ha brindado la posibilidad a muchos de ellos y ellas de sentir que sus aportes son valiosos y significativos, y algo muy particular es que han sentido que investigar no es de "doctores" (Comentario de Carlos Martínez. Encuentro Abril de 2016), y que lo que ellos y ellas tienen para decir es muy importante y valioso para la construcción de conocimiento.

Es un desafío importante que implica para mí como docente y participante activo del semillero reconocer que podemos formarnos a partir de estas racionalidades y subjetividades y que por ende esto no debe limitarnos a la simple transmisión de información o contenidos.

Personalmente he hecho un paralelo entre los y las jóvenes que asisten al semillero y los que no participan de éste. Esto me ha permitido reflexionar y llegar a concluir que entre una y otra existe una gran diferencia aun cuando los y las participantes son esos mismos jóvenes que asisten a clase pero que es evidente y muy notorio en el aula de clase una marcada diferencia en el hecho de que al semillero asisten por interés personal, por una motivación intrínseca y por su deseo de libertad. Libres, esto es talvez lo que para ellos y para mi marca una verdadera diferencia, en el semillero somos libres de opinar, de juzgar, de cuestionar, de asumir nuestra ignorancia frente a algún asunto; mientras que en el aula somos otros, nos mostramos más cohibidos, existe una necesidad tácita de poder, la preocupación por pasar una asignatura y de mi parte de estar calificando hace que esa relación que se teje en el semillero se pierda un poco en el aula. Sin embargo, evidencio mayor empoderamiento de los y las jóvenes que participan del semillero en 
cuanto a sus niveles de argumentación.

Con los y las participantes que más tiempo hemos compartido encuentros en el semillero y con la colaboración de uno de los compañeros del área de sociales hemos hecho el ejercicio de iniciar la sistematización del mismo.

Es interesante reconocer cómo estos jóvenes con el paso de las sesiones tienden a prepararse más en sus argumentos y a intentar encontrar diversas y variadas opiniones, teorías o ideas frente a una misma situación. Ver como sesión tras sesión se asombran, se incomodan, se sorprenden de sus propias ideas, como las modifican o las corroboran es muy satisfactorio.

Haciendo una primera síntesis, un paso importante es que los y las participantes han manifestado que ha sido un reto para ellos asumir la filosofía de una manera distinta a la forma convencional a como la han asumido.

Por otro lado, las sesiones del semillero además de las visitas hechas a la Universidad Santo Tomas y su relación con algunos docentes de la Maestría en Filosofía Latinoamericana, nos han modificado la manera como asumíamos la filosofía. Tener claro que la producción de conocimiento dista de la idea de acumulación de información representa en sí mismo una demostración de que la participación en el semillero conduce a un pensamiento reflexivo e imaginativo. El semillero se ha constituido como un espacio democrático, que estimula la participación creativa de los y las participantes en la búsqueda de nuevos conocimientos y que asume la investigación como herramienta pedagógica y de sustento de la autonomía académica.

En el semillero de investigación en Filosofía Latinoamericana los y las estudiantes de los grados décimos y once del colegio CODEMA IED, han construido un proyecto de reconocimiento de su realidad y han ido sistematizando esta experiencia. Esto se ha logrado a través de la implementación de ejercicios de deliberación y registro de cada una de las sesiones.

\section{Sistematización}

Con la sistematización de las experiencias obtenidas como producto de las sesiones de trabajo llevadas a cabo por los y las jóvenes participantes del Colegio CODEMA IED y de su maestro de filosofía como grupo activo del semillero de investigación en filosofía latinoamericana 
INTUS LEGERE, se pone de manifiesto cómo el reconocimiento de sus realidades y el trabajo en torno a la filosofía latinoamericana promueven acciones al logro de la transformación de dichas realidades.

La tarea de sistematización se pensó en una estructura de dos niveles de análisis. El primer nivel corresponde al análisis de los relatos elaborados por los y las participantes en los cuales se condensa su experiencia en el semillero y a las categorías que de allí se derivaron como: Percepción y transformación de la realidad y la influencia del pensamiento filosófico latinoamericano en el reconocimiento de una identidad. El segundo nivel de análisis se desarrolla en torno a la transformación de la práctica docente del maestro de filosofía que acompaña a los y las estudiantes del Colegio CODEMA IED, fundamentado en el reconocimiento de la Práctica sobre la teoría.

La primera parte de este documento aborda de manera crítica el proceso de la sistematización, la producción de los relatos y las rutas construidas para el análisis de los mismos. Se exponen los hallazgos obtenidos de acuerdo a las categorías propuestas por la sistematización y deja planteados interrogantes fundamentales para la comprensión de la realidad, de la identidad y del proceso del semillero. En la segunda parte se analiza de manera general los cambios de pensamiento, de los y las participantes como producto del trabajo realizado en el semillero. Y por último se evidencia en los relatos y los ejercicios realizados en las sesiones del semillero la sorprendente riqueza de las reflexiones de los y las participantes frente a su realidad, al pensamiento latinoamericano, a la identidad como portadores únicos de una cultura, a su idea de filosofía, de la vida misma.

Espero que con este ejercicio de sistematización se puedan hacer aportes significativos al ejercicio práctico de la filosofía en las aulas, a la construcción de conocimiento colectivo que surge del reconocimiento de la realidad de sus participantes, y a la ampliación de la mirada del que hacer filosófico en la estructuración de un pensamiento crítico de los y las jóvenes del Colegio CODEMA IED.

\section{Hacia un análisis de los relatos.}

El semillero de investigación INTUS LEGERE, conformado por jóvenes entre los 14 y 18 años de edad y su maestro de Filosofía de la institución CODEMA IED, han venido abordando en 
sus sesiones variados ejercicios de indagación, consulta, debate, concertación y reflexión frente a temas como: el papel de la filosofía en la escuela, que es ser filósofo, para qué sirve la filosofía, que es la vida, que es la realidad, que es la verdad, porque se habla de filosofía latinoamericana, porque no nací gringo o europeo, como puedo cambiar lo que soy, porque somos como somos, que debo hacer para ser filósofo, porque la filosofía es aburrida, de que sirve conocer de dónde venimos, como la filosofía puede cambiar mi vida, entre muchos otros. Todos estos ejercicios fueron compilados en cuatro relatos en torno a tres aspectos que a juicio de los y las participantes sintetizan el resultado de sus reuniones: De dónde vengo y para donde voy; Preferible ser latinoamericano que europeo, Mi realidad, tu realidad, nuestra realidad... son susceptibles de ser modificadas y Filosófate la vida.

Los resultados del análisis de estos relatos se encuentran delimitados por condicionantes como: la falta de precisión conceptual, las carencias en las pautas de escritura y redacción de estos jóvenes, sin embargo evidencian una producción colectiva que da cuenta de todos los testimonios de sus participantes, de su proceso de aprendizaje continuo y particularmente de su interés y motivación.

\section{Los participantes y sus características.}

Los y las participantes son doce jóvenes estudiantes adscritos al semillero de investigación de los grados décimo y once del Colegio CODEMA IED, el maestro de filosofía y el maestro de ciencias sociales de la jornada mañana.

El contexto social- influye en el aprendizaje y la educación, para poder analizar este fenómeno educacional debemos primero, determinar qué es el contexto y los tipos de contexto existentes para entender de una manera más clara y precisa este tema.

El contexto se refiere a un conjunto de circunstancias en las que se encuentra situado un hecho, en nuestro tema el contexto solo tomaría una faz educativa es decir, la que se refiere a la influencia que tienen las circunstancias sociales que rodean una escuela en el aprovechamiento de sus alumnos, es decir al espacio en que se encuentra ubicada la institución educativa y el nivel económico social y cultural de la comunidad (Tomado de Caracterización y Análisis poblacional COLEGIO CODEMA IED 2015). 
El Colegio Distrital CODEMA se encuentra ubicado en la Localidad de Kennedy del Distrito Capital, específicamente dando respuesta a las necesidades educativas de la población de la Localidad y de la Ciudadela La Primavera, sector barrial de Patio Bonito, contexto en el cual se encuentra la institución educativa.

Los y las estudiantes sobre los cuales se apoya el semillero hacen parte de los grados décimo y once, que oscilan entre los catorce y dieciocho años de edad, quienes de acuerdo a la Caracterización y análisis poblacional que la Institución realizó en el año 2015 presentan las siguientes características sociales, económicas y culturales: En cuanto a la vivencia se nota la presencia de un número mayor de familias nucleares (padres, hijo y hermanos) con las que viven los estudiantes, seguidos de familias donde solamente hay padres, lo cual significa que existe un buen número de hijos únicos. Es alto el número de estudiantes que viven solamente con la madre. Por el tipo de actividad de la madre, la mayor parte de los estudiantes comparten el día con los hermanos. No existe un número muy alto de estudiantes que viven solos. Es bajo el número de estudiantes que tienen hijos o que están en el momento de la encuesta embarazadas.

Otras de las características que presentan son: Las familias están conformadas por padres que superan los cuarenta años (tanto madre como padre). En cuanto a ocupación se evidencia que los padres en su mayoría son empleados y un grupo también importante trabaja de manera independiente. Para el caso de las madres son más las empleadas. Con respecto a la formación de los padres la mayor parte están entre secundaria completa e incompleta. El nivel de formación en educación superior es bastante bajo.

Casi el total de familias viven en arriendo. En general las familias pueden acceder a los servicios públicos, se evidencia un número significativo que tiene acceso a TV cable e internet, lo que significa que el servicio se viene masificando. La mayor parte de la población está inscrita en el subsidiado de salud. Hay un grupo de familias que no tienen este servicio.

Por la conformación de las familias, la mayor parte de los estudiantes viven con sus padres y hermanos. Hay un destacado número de familias nucleares, que además de permitir un acompañamiento a los estudiantes, contribuyen al sostenimiento de las familias. Hay una correspondencia entre la presencia de ambos padres y la contribución de éstos a nivel económico. En orden de conformación aparecen familias con ambos padres y un hijo(a) único, cuando ello 
sucede, parece que empieza a establecerse la relación con familias donde el aporte económico lo da el padre y la madre se encarga tanto del cuidado de su hijo(a) como de las actividades del hogar.

En el contexto donde se ubican las familias del colegio, hay algunas familias en la que la cabeza del hogar es la madre, en un muy bajo nivel el padre. Ellas pueden ser las familias donde el aporte económico es solamente de uno de los padres. En un bajo nivel están las familias extensas, es decir, donde conviven padres, hijos, abuelos y tíos como sucede en alguna de la información proporcionada por los jóvenes.

Estos tipos de organización familiar también permiten establecer varias coincidencias, si bien las encuestas realizadas por el equipo encargado de realizar la caracterización y análisis poblacional de la institución no precisan si el estudiante que indicó que vive con sus dos padres y hermanos, está acompañado de su madre en casa, por lo que se deduce que: cuando hay ambos padres y los dos trabajan, los hijos se quedan con sus hermanos. Cuando hay los dos padres y un solo hijo la madre se encarga de su cuidado. Cuando hay un solo padre/madre con los hijos, el cuidado está en los hermanos mayores (si los hay) o en enviar al niño a personas encargadas del cuidado, entre ellas pueden ser los abuelos o los tíos. Existe una proporción alta en la mayoría de los estudiantes que se quedan solos una vez terminan sus actividades académicas en el colegio.

La mayor parte de las familias del colegio están ubicadas en estrato uno y dos, muy bajo es el número de familias en estrato tres. Si se alcanza a evidenciar algunos bajos porcentajes que están por debajo del estrato uno, y que se evidencia en correspondencia con los niveles salariales. En el nivel de ingresos de las familias encontramos que la mayor parte perciben un salario mínimo, sólo cuando los dos padres trabajan hay la presencia de ingresos correspondientes a dos salarios mínimos. Solamente en un curso se evidencio un nivel muy bajo de familias con ingresos iguales a dos salarios mínimos. Es de reconocer que también existen familias con ingresos menores a un salario mínimo y en algunos casos desempleados.

El contexto en el que se encuentran inmersos los y las participantes es significativo en la manera como estos jóvenes asumen su diario vivir y se desenvuelven con su comunidad pero no es determinante para su accionar. Fals Borda plantea que solo a través del reconocimiento de este y de la investigación sobre sus características y necesidades se puede llegar a una transformación. Es significativo en la medida en que hace parte de sus vidas, pero solo si los y las participantes 
reconocen la manera como este influye, como impacta sus vidas, como puede llegar a ser determinante en su accionar personal y colectivo se podrá verdaderamente llegar una transformación.

Por otro lado, es importante anotar que en su mayoría muestran algunas deficiencias del orden cognitivo, presentan dificultad para relacionar, deducir, analizar, y conceptualizar. Son jóvenes que leen muy poco y que construyen sus opiniones de acuerdo a lo que escuchan en T.V, sus padres y amigos, y son muy pocos los que buscan ampliarlas o argumentarlas con otras referencias. Tienden a guiarse por las noticias que aparecen en sus redes sociales como lo argumentaron algunos de ellos: "yo lo que se de noticias del mundo es porque sale en el face porque o si no no tengo ni idea que pasa, a mí no me gusta ver noticieros y además ahí dicen solo lo que les conviene” (Afirmación de Claudia Prieto. Encuentro Septiembre de 2015). “¿Leer periódicos? En la casa nunca se compra de eso y para que, si todo lo puede uno leer en el face o en internet, ahí se entera de lo que uno quiere saber" (Afirmación de Juliana Alvarado. Encuentro Septiembre de 2015).

\section{Representatividad.}

La representatividad de los participantes fue determinante para poder dar cuenta de todos las opiniones y argumentos que hicieron parte del semillero, así que se instó a aquellos que en algún momento participaron y que por situaciones ajenas no pudieron continuar pero que igualmente aportaron al semillero a que se unieran en la construcción de esos relatos. Por otro lado se tuvieron en cuenta las memorias, las actas, los audios y los videos que se han venido realizando en las sesiones del semillero para la construcción de los relatos.

Los participantes se organizaron por grupos de acuerdo a su interés o por su mayor apropiación del eje de trabajo de cada relato. No obstante, algunos de ellos aportaban a los otros grupos, el ejercicio de construcción de esos relatos en ocasiones tenía que rehacerse porque algunos de sus participantes no asistían, y cuando nuevamente se retomaba el trabajo en ellos había confusión.

En el transcurso del proceso de construcción de los relatos los y las participantes se vincularon en su totalidad a los ejes de trabajo colectivo, sin embargo, con los y las participantes 
que ingresaron en la etapa final fue compleja su vinculación pues no lograban consolidar una postura o una idea, debido a que no habían participado en las sesiones de discusión anteriores.

\section{Metodología.}

\section{Pautas para elaboración de los relatos.}

En los últimos dos encuentros se convocaron a todos los integrantes del semillero para seleccionar de toda la información recolectada (audios, entrevistas, debates, actas, ejercicios de análisis, lecturas, etc.) a lo largo de su funcionamiento aquellos que realmente se consideraran significativos y de esta manera los y las participantes los agruparon en los siguientes ejes de desarrollo:

a. De dónde vengo y para donde voy;

b. Preferible ser latinoamericano que europeo,

c. Mi realidad, tu realidad, nuestra realidad... son susceptibles de ser modificadas y

d. Filosófate la vida.

Este ejercicio colectivo, llevó en un principio al planteamiento de muchos más ejes, pero poco a poco se fueron conglomerando en los antes mencionados, buscaron que centrara todo el trabajo que ha hecho el semillero a lo largo de este tiempo y que diera cuenta de esa búsqueda en la que se han encausados sus participantes.

Para la construcción de los relatos se hicieron ejercicios de consolidación de la información, sin embargo solo hemos podido avanzar en la construcción de relatos en torno al eje de "Mi realidad, tu realidad, nuestra realidad... son susceptibles de ser modificadas, atendiendo a:

a. Talleres ejemplificadores, donde después de presentar un texto (cuento, relato) o ver un documento, se hacían una serie de preguntas en torno a los componentes del relato trabajado y así lograr que este realmente abordara todo lo relacionado a dicho eje de desarrollo. 
b. Talleres inductivos: en los cuales se instó a los y las participantes que de acuerdo a su participación en el semillero construyeran relatos individuales o colectivos para así complementarlos con toda la información aportada por el semillero.

c. Talleres Sensibilizadores: estos buscaron que los y las participantes se sintieran más tranquilos y perdieran el miedo a escribir y de esta manera presentaran las características de sus relatos con mayor tranquilidad.

En general se hizo un acompañamiento por parte del maestro de filosofía, que si bien él es participante del proceso también apoyó el ejercicio de sistematización y este lo hizo en los siguientes momentos:

1. En la sensibilización y conceptualización del relato

2. En la asesoría para avanzar en la escritura del relato

3. En el ejercicio de socializar los relatos individuales para luego construir los colectivos.

4. En la búsqueda de posibles hallazgos

5. En los aportes al ejercicio de escritura.

Para finalizar todos los participantes en el encuentro de Febrero de este año se hizo la lectura de todos los relatos y fueron a partir de estos que se condensaron en los ejes de desarrollo antes mencionados y sobre los cuales se agruparon, estos textos como lo mencionamos en la descripción de los encuentros (ver anexos).

Vale la pena resaltar que para algunos de los y las participantes el ejercicio de escritura y aun con el acompañamiento se generaron dificultades para culminarlos en los tiempos previstos, ellos y ellas daban cuenta de sus limitaciones en la construcción de textos, en las deficiencias incluso de su nivel de argumentación, de relacionar, de sintetizar y además algo a destacar es que todos aun cuando era un mismo tipo de texto cada uno denotaba su estilo propio de escritura. 


\section{El proceso de escritura.}

Pese a que en el semillero se realizan tareas de consolidación de la información, escritos y ponencias, aun se evidencian las dificultades para escribir y plasmar todas sus ideas. Muchos de ellos manifestaron temor, vergüenza ante otros que los fueran a leer y que fuesen enjuiciados por otros. Sus escritos tienden en gran medida a buscar referentes en internet e incluso a copiarlos. En su mayoría toman conceptos de otros y poco expresan sus puntos de vista y si lo hacen tienden a ser imprecisos, evasivos y cargados de mucha emocionalidad, aquí algunos apartados de ellos:

Relato de Yuri Bernal Tabares: "En mi opinión lo que más ve la gente de importante son las clases sociales porque aquellos que tienen plata lo consiguen todo y lo pueden tener más cosas no lo valoran, en cambio la clase social baja tiene poco y lo que tienen lo valoran y le sacan provecho de ello"

Relato de Johan Steven Benavides: "Estamos sometidos a la influencia de los medios informativos, obligados a montarnos en el tren global del mercado, a riesgo de sucumbir económicamente, no escapamos al régimen financiero globalizado que impera el mundo".

Relato de Andrés Felipe Arenas: "somos jóvenes que queremos comernos el mundo, pero que todo aquí es prohibido y por eso dicen lo prohibido es apetecido, entre más nos digan que no debemos hacer algo, más lo vamos a hacer... Yo nací pobre y en la mala y así seguramente me voy a quedar, aquí no hay oportunidades, todos somos nada para el resto".

La mayoría se construyen sobre la queja, el reclamo a la sociedad imperante:

Relato de Yamandú Acosta: En mi país no tenemos oportunidades, solo los que tienen poder y dinero pueden acceder a todo, nosotros debemos salir a buscarlas, ellos nacen y ya las tienen. La realidad de un joven del colegio está dada por la necesidad de abrirse camino poder trabajar y si le va bien poder estudiar en una universidad, nos dicen que los pobres somos agradecidos y que valoramos más lo que tenemos si fuera así porque nos matamos entre nosotros mismos? 
Emplean mucho la pregunta para desarrollar sus argumentaciones:

Relato de Alejandra Rojas: ¿ésta es la realidad que yo pedí?, ¿acaso alguien me preguntó si quería ser pobre?, yo no lo decidí, a mí me tocó por suerte, porque a alguien se le ocurrió?, en fin ... son muchas las preguntas que nos hacemos los jóvenes al ver a otros que pueden estudiar, viajar y nosotros nos debemos conformar y sentirnos bien porque podemos comer... ¿ellos tienen mejor educación? Si, y por eso les va mejor y tienen mejores oportunidades. A nosotros nos dan una educación para que seamos siempre pobres e ignorantes, pero la pregunta fundamental es ¿podemos hacer un cambio? ¿Podemos dejar de ser los pobres del sistema?, ¿podemos exigir una educación que sea equitativa para todos?...

Se mueven entre lo que se supone es el deber ser y lo que quisieran que fuese:

Relato de Nathalia Barón: La realidad de un joven colombiano es una algunas veces difíciles porque tenemos que ser casi obligados a cumplir con ciertas cosas de las cuales no estamos de acuerdo, pero que sabemos que debemos hacerlas. Es complicado, porque todos deberíamos participar en esa toma de decisiones, pero pues a veces ni nosotros mismos participamos, por ejemplo, hay protestas que nos ayudan a todos pero no vamos o si vamos es para hacer cosas violentas y así no nos ponen cuidado.

Se evidencia dificultad a la hora de escribir sus ideas que al expresarlas verbalmente son llenas de sentido pero que al hacerlo por escrito se desvanecen. Estos jóvenes tienden en su gran mayoría a escribir como hablan (Relato de Sebastián Barrios: "Vivir así es una mamera, tenemos que ser lo que los otros nos dicen, en todo momento dentramos a decir lo que pensamos y nos cogen entre ojos, estamos buliniados por decir lo que pensamos"; poco buscan el perfeccionamiento en sus textos, es decir cuando se les pide buscar sinónimos o antónimos que contribuyan al mejoramiento y clarificación escritural inmediatamente expresan desencanto. Escribir y leer no son procesos afianzados ni hábitos propios de los y las participantes del semillero.

\section{Categorización.}

Analizar un texto requiere del establecimiento de unas categorías que nos permitan dar cuenta del mismo y estas son previas al análisis mismo y surgen de las concepciones que posea el 
lector. También podemos emplear subcategorías, las cuales se infieren en la medida que se realiza el análisis. Tanto las categorías como las subcategorías son susceptibles de ir variando en el proceso de análisis. Por otro lado, es necesario establecer relaciones entre las categorías para poder llevar a cabo un mejor proceso de análisis.

Algunos de los relatos en ocasiones no ofrecían suficiente información por lo que establecer las categorías fue bastante complejo. De ahí que se tuvo que volver a solicitar hacer el ejercicio de escritura con mayor acompañamiento para así lograr un mejor análisis.

Las dificultades en la conceptualización hicieron que en algunos relatos por ejemplo el concepto de realidad variara sustancialmente en relación a otro:

Texto 1: La realidad es personal, cada uno vive su vida a su acomodo y antojo. MI realidad es única, y solo yo la puedo transformar...

Texto 2: La realidad es de todos y todos tenemos el compromiso de transformarla para el bien común...

Texto 3: Solo existe una realidad y todos hacemos parte de ella, es la que nuestros ojos quieren ver, o es la que otros quieren que veamos, es nuestra decisión asumirla como tal...

Esta discrepancia nos obligó a establecer la categoría de la realidad con subcategorías como: a). la realidad como una construcción personal b) la realidad como una construcción colectiva. De igual manera se presentó en otros conceptos como: verdad, herencia, identidad entre otros.

El grado de profundización y de conceptualización en los relatos es escaso, Sin embargo, su valor radica en que son propios y el hecho de ser anecdóticos dan cuenta de su verdadero sentir, buscan ser críticos desde su realidad, su emocionalidad para poder comprender porque viven o actúan de determinada manera, solo cuando dan cuenta de ello comienzan a buscar formas posibles de cambio y transformación. Aquí vemos como esa construcción colectiva de conocimiento, producto de los debates, de las deliberaciones ha permitido en ellos identificarse como lo que son para dar ese salto a la transformación de su realidad: 
Relato de Sergio Iván Orjuela: Llevo asistiendo al semillero desde el 2016, cuando empezamos, yo asistía por escapar de mi casa, pero con el paso del tiempo y encuentro tras encuentro me fui integrando más, pude ver en mí, cualidades que nunca ni mis padres, ni los profesores y ni siquiera yo sabía que tenía. Me di cuenta que había otros que pensaban como yo, otros que se preguntaban lo mismo que yo: ;si esta vida que nos tocó vivir la podríamos cambiar!, no como los adultos nos dicen que solo estudiando seremos alguien, porque los médicos también matan, los jueces son corruptos, los políticos son asesinos, y ellos estudiaron mucho, es para cambiar de verdad, para cambiar lo que realmente es importante, no para tener cosas sino para ser diferentes de verdad. En el semillero he visto como si no me reconozco ni tampoco reconozco la realidad en la que vivo, solo cambiaré para mí, pero y ¿los demás dónde quedan? Seguir aguantando que nos den una educación para pobres, aceptar que nos pongan impuestos, entre otras. Pero no puedo cambiar sino sé cómo es y cómo me afecta.

Vemos en ellos procesos de reflexión que son necesarios seguir fortaleciendo, apoyándolos en el afianzamiento de su argumentación pero es evidente que el espacio del semillero ha permitido que jóvenes que se sentían inmersos en una realidad que a simple vista era la de otros, comiencen a encontrar eco con sus pares, en sus ideas e imaginarios.

El proceso de sistematización se encuentra aún en proceso, pues solo alcanzamos a analizar una de las categorías. Debido a que los tiempos de reunión cada vez están más limitados. Pero seguimos desarrollando e implementándolo sobre los ejes antes mencionados.

\section{Análisis de mi práctica pedagógica}

Mi práctica pedagógica ha evidenciado transformaciones muy importantes, encuentro como he logrado conjugar y dar mayor espacio a los procesos de reflexión y argumentación en el aula sin sentir que estoy dejando de lado los contenidos curriculares impuestos. De otro lado he tratado de incluir con mayor fuerza la filosofía latinoamericana en la planeación curricular de la asignatura. No obstante, sigue siendo apremiante el tiempo el cual es muy corto para el ejercicio de reflexión, análisis y argumentación que he integrado a mi práctica. 
Convertirme en un profesional reflexivo ha sido uno de los objetivos que me he configurado, hacer de mi ejercicio docente una práctica constante de investigación, una opción de cambio y transformación que impacte de alguna manera a los y las estudiantes que día a día pasan por mi salón.

Vincularlos en procesos de investigación y construcción de conocimiento dando valor a lo que son, a lo que dicen y expresan, a la realidad como fuente de estudio. Reconocer que solo en ese ejercicio participativo encuentro la motivación necesaria y que ya las demás estrategias aun cuando son importantes no son suficientes puesto que solo permitiendo escuchar y ser escuchados a los y las jóvenes se logrará el impacto que como docente siempre he esperado.

Asumir la investigación acción participación como uno de los instrumentos que apoyan el proceso de reflexión y análisis filosófico y educativo puesto que permite que la investigación sea desde la acción y la participación misma como su nombre lo dice y da voz y voto a todos los actores que en ella participan, tiene en cuenta el saber popular, y busca a partir de ello construir conocimiento que redunde en la transformación de sus actores.

\section{Conclusiones del proceso con el semillero}

El desarrollo de la presente investigación nos aporta como conclusiones lo siguiente:

1. La creación de comités por enfoques social, político, económico, cultural entre otros ha logrado que los y las estudiantes en sus procesos de discusión y construcción de conocimiento y de resolución a una problemática en particular, promuevan un sentido crítico ante su realidad reconociendo las diversas formas de tratarse una situación, una pregunta o una aseveración. Esta manera de abordarlas les permite a través de sus propias reflexiones construir una idea propia y argumentada.

2. Por otro lado, tener como eje la generación de una sensibilidad ante la realidad, ha constituido un reto, se han realizado sesiones en las que ellos y ellas plantean problemáticas comunes, tratando de desarrollarlas bajo distintas ópticas por ejemplo si el problema de la venta de bazuco de la esquina del barrio es responsabilidad de la policía, del Gobierno, de la Junta de Acción comunal, de la gente de la cuadra, del barrio o de los jóvenes que van allí a comprarla. Esta manera de abordar algunas problemáticas ha logrado 
calar en ellos una actitud menos prejuiciosa y condicionada. Son este tipo de sesiones que los lleva a subvertir el orden establecido y la manera de abordar un problema.

3. El desarrollo de un pensamiento crítico es un proceso que se construye a largo plazo, con los y las participantes se ha logrado un acercamiento al sentido del mismo sin embargo aún nos falta mucho camino por recorrer, se logró que los y las participantes se preguntaran por su realidad, se motivaran a su estudio y construyeran conocimiento a partir de ello.

4. Uno de los logros fundamentales en este ejercicio es el cambio en la idea de la filosofía y quienes hacen filosofía que tenían estos jóvenes, en la manera como evidenciaron que a partir de su saber propio, de su sentido común se puede construir conocimiento y se puede hacer investigación.

5. El impacto en las vidas de los y las participantes ha sido muy significativo, les ha permitido escuchar y ser escuchados, les ha dado más opciones a la hora de dar respuestas a los problemas planteados en la realidad y contexto en el que viven. Algunos de ellos han construido un proyecto de vida diferente.

6. La comunidad educativa (padres, maestros, directivas) han evidenciado un nivel de compromiso mayor y de los y las participantes en las situaciones que se viven a diario, las familias comentan que son más críticos ante los medios de comunicación y que se preocupan más por el devenir de su país y los problemas que tenemos. Las directivas han dado cuenta de su interés por participar en las decisiones que se toman por ejemplo en el manejo de los recursos, e incluso han sugerido que el semillero no sea solo para aquellos que pueden asistir en las tardes, sino que se amplíe la intensidad horaria de la asignatura de filosofía. Los maestros que tienen en sus aulas a estos jóvenes afirman que muestran mejores niveles de argumentación.

7. El semillero como propuesta alternativa para estos jóvenes ha logrado convertirse en un espacio de reflexión, discusión, y análisis de la realidad, una construcción colectiva que de alguna manera y otra permea a todos los que hemos participado o participamos en él, nos ha modificado la manera como se asume la investigación, como se 
construye conocimiento, nos ha permitido ahondar en nuestra realidad para confrontarla, dinamizarla y reconocerla.

8. Como docente he logrado modificar la estructura curricular de la asignatura en filosofía al interior del colegio CODEMA, he afianzado la Filosofía Latinoamericana como un estudio juicioso dentro de la estructura de contenidos.

9. Me encuentro en el ejercicio práctico de ser un maestro reflexivo, el dar cuenta que desde el aula, desde el saber popular, del sentido común podemos construir conocimiento, y poder permitirme a partir del estudio de la realidad investigar, con miras a transformarla ha sido un gran salto en mi profesión.

\section{Conclusiones generales}

A lo largo de estas páginas se ha reiterado sí la creación de un semillero de investigación y la sistematización del mismo son una vía pedagógica idónea para promover la generación de conocimiento sobre la base del reconocimiento de la realidad de los y las jóvenes con miras al logro de su transformación y a la generación de un pensamiento crítico. Con base en mi experiencia con el semillero Intus Legere puedo afirmar que aun cuando esta transformación no esté del todo expuesta en procesos de movilización visibles a agentes externos, el solo hecho de abrir la posibilidad a sus participantes de exponer sus argumentos, sus ideas, sus creencias, sus problemáticas y discutirlas, analizarlas, reconocerlas y encontrarse con otros que de alguna manera también las viven, generó un cambio importante en ellos. La mirada colectiva sobre alguna situación les permitió dar cuenta que a partir de esas vivencias se puede construir conocimiento.

Por otro lado, esta experiencia posibilita encuentros más desde lo que los y las jóvenes esperan y desean, más comprensión sobre lo que viven y lo que sienten, en esta medida como ejercicio pedagógico es recomendable para todos aquellos docentes que buscan procesos de reflexión de su práctica pedagógica. Estos espacios posibilitan la construcción colectiva de 
conocimiento y no el simple cumplimiento de logros fundados en la repetición y memorización de datos.

Como todo proceso requiere ajustes y tiene limitaciones. Una de ellas es el tiempo, ya que los y las participantes deben dar cuenta de otras tareas propias de su rol lo que les impide participar de manera continua, debido al cúmulo de actividades curriculares y extracurriculares que tienen. Otra limitante son los espacios ya que la institución se encuentra aún con la doble jornada y esto hace que no se pueda contar con el espacio previsto. De igual manera encontramos que se requiere un proceso reeducativo con las familias en cuanto al valor que tienen áreas de estudio como la filosofía en la sociedad, ya que para muchos de ellos esto era una pérdida de tiempo impidiendo así que sus hijos pudieran asistir.

Quisiera resaltar que la implementación de la estrategia llevó a reestructurar la idea que se tenía de que sólo se puede hacer investigación en determinadas áreas, generando en la comunidad educativa gran inquietud por lo que se hacía en el semillero. Esta es una estrategia que posibilita un mayor acercamiento entre el estudiante y el maestro, y rompe totalmente esa estructura vertical y generen una mayor apropiación de la investigación ya que todos son protagonistas del mismo; en este sentido la recomendaría para ser aplicada en todas las instituciones.

Para el abordaje del problema investigación encontramos en que la investigación acción y la investigación acción participativa fueron de gran ayuda en el desarrollo metodológico de la propuesta, así como los referentes teóricos de sus actores. Orlando Fals Borda desde sus aportes posibilitó el dar valor sustancial al diálogo abierto de saberes como fuente primordial para los procesos de investigación colectiva en el semillero de investigación; James Mckernan y Donald Shön permitieron ahondar en lo que significa ser un profesional reflexivo y como desde allí, desde el mismo quehacer como maestro se pueden generar transformaciones colectivas.

Una práctica pedagógica que conduzca a la construcción colectiva de conocimiento, que estructure espacios y escenarios de resistencia que permita la participación continua y de valor a ese saber popular, a ese sentido común, a esa filosofía espontanea, se consolidará como una práctica reflexiva, transformadora de las realidades de quienes hacen parte de ella. 
La invitación es a que le apostemos a hacer de nuestra profesión como docentes en filosofía, un proceso continuo de reflexión y a que integremos a la estructura curricular espacios como los semilleros de investigación en filosofía latinoamericana para que desde esa construcción colectiva y desde la acción misma se legitimen verdaderas transformaciones en las realidades de nuestros estudiantes.

Este es un proceso continuo de mejora, es un camino al que gracias a mis estudios en filosofía latinoamericana y a este proceso de investigación con el semillero Intus Legere he podido sembrar la semilla de la reflexión pedagógica en mi profesión. Deseo continuar en el proceso de sistematización de esta experiencia así como brindar a la comunidad educativa puntos de partida para el análisis de las problemáticas y situaciones de la realidad propia que viven nuestros jóvenes que hacen parte de nuestra institución y si de esta se derivan procesos de formación en pensamiento critico y que muy seguramente con el afianzamiento de estos procesos se pueda lograr en estos jóvenes la construcción de un pensamiento latinoamericano identitario; siendo esta también una de las apuestas del semillero planteadas a largo plazo.

Invito a la comunidad docente del área de filosofía a que generemos un mayor acercamiento a nuestras raíces y al conocimiento latinoamericano, a que nos permitamos junto con nuestros estudiantes construir otras posibilidades de aprender y desaprender.

«Hay tres tipos de personas en el mundo:

los inamovibles, los movibles y los que se mueven»

Benjamín Franklin 


\section{Referencias Bibliográficas}

Camacho, A. (1986). La investigación acción-participativa: politica y epistemologia. En A. Camacho, La Colombia de hoy, sociología y sociedad. (pág. 206). Bogotá D.C: Cerec.

Fals Borda, O. (1978). Por la praxis: el problema de como investigar la realidad para transformarla.

Fals Borda, O. (1981). La ciencia y el pueblo: nuevas reflexiones sobre la investigación -acción. In La sociología en Colombia: balance y perspectivas, Memoria del Tercer Congreso Nacional de Sociología. Bogota D.C.: Asociacion Colombiana de Sociología.

Fals Borda, O. (2009). La crisis, el compromiso y la ciencia. En O. Fals Borda, Una Sociología sentipensante para América Latina 1925-2008 (págs. 219-252). Bogotá: CLACSO Coediciones. Siglo del Hombre Editores.

Fals Borda, O. (2013). Socialismo raizal y el ordenamiento territorial. Bogotá D.C.: Desde abajo.

Freire, P. (2001). Reflexion critica sobre las virudes del educador. Bogota: Mimeo.

Marimón., F. B. (2009). Los semilleros como espacio de iniciación en investigación. Uni-pluri-versidad, $8(2)$.

Mckernan, J. (1999). Investigación- acción y curriculum: métodos y recursos para profesionales reflexivos. En J. Mckernan, Analisis del discurso y métodos de investigación basados en la resolución de problemas. Morata.

Molineros.G, L. (2009). Epistemologia de los semilleros de investigación y la cultura en la Redcolsi. En L. F. Gallón, Origenes y dinámica de los semilleros de investigación en Colombia (págs. 117-145). Medellín- Antioquia: Universidad del Cauca y de Antioquia.

Ocampo, J. (2009). El maestro Orlando Fals Borda sus ideas educativas y sociales para el cambio en la sociedad colombiana. Revista Historia de la Eduación Latinoamericana, 12, 13-41.

Piedad Ortega, Diana Peñuela y Diana M. Lopez. (2009). Sujetos y practicas de las pedagogias criticas. Bogotá: Editorial El Buho.

SHON, Donald. A. (1998). El profesional reflexivo. Barcelona: Ediciones Paidos. 


\section{Apéndice 1}

\section{Realidad o ficción}

\section{Jeimy Natalia Moyano Ordoñez y Yamandú Acosta *}

El concepto de realidad a mi opinión es abstracto, pues real es todo aquello que hacemos, que palpamos, que vemos, pero siempre hay algo más allá de lo que nosotros creemos que es el mundo. Mi realidad como estudiante de undécimo de un colegio cualquiera es una rutina monótona, en este instante de la vida, después de 11 años ya quizás tenemos en mente salir de esta zona de confort, que para ser sinceros no conocemos aun, vivimos rodeados de problemas sociales que no solo influye el estrato social en el que me encuentro, sino que también la historia de mi país, y los pensamientos que después de varios años de sangre y poder han influido en los diversos ideales y en lo materialistas que nos hace la sociedad. En mi país no tenemos oportunidades, solo los que tienen poder y dinero pueden acceder a todo, nosotros debemos salir a buscarlas, ellos nacen y ya las tienen. La realidad de un joven del colegio está dada por la necesidad de abrirse camino poder trabajar y si le va bien poder estudiar en una universidad, nos dicen que los pobres somos agradecidos y que valoramos más lo que tenemos si fuera así porque nos matamos entre nosotros mismos?

\section{La realidad de un joven colombiano.}

\section{Alejandra Rojas y Nathalia Barón:}

Antes de iniciar quiero aclarar que voy a hablar de mi generación, del fruto que puedo ver después de varios años de historia. La realidad de un joven colombiano es relativa pues como en todo, hay millones de pensamientos, de formas de ocupar su tiempo, de rutinas, pero todas ellas van unidas a un mismo factor: cultural, sistema social, político y económico que rigen a nuestro país, somos una generación la cual tiene muchas más herramientas, pero no todo es bueno, también hemos sufrido un lavado de pensamiento, nuestra historia hace lo que somos, y muchas de ellas son la avaricia, el poder, cosas materiales. La realidad mía es trabajar, estudiar, hacer parte de un entorno con miles de dificultades, como ver el estigma que tienen por el estrato en el que me ubico, imaginar y esforzarme para mejorar y contribuir a lo que somos. ¿ésta es la realidad que yo pedí?, ¿acaso alguien me preguntó si quería ser pobre?, yo no lo decidí, a mí me tocó por suerte, porque a alguien se le ocurrió?, en fin ... son muchas las preguntas que nos hacemos los jóvenes al ver a otros que pueden estudiar, viajar y nosotros nos debemos conformar y sentirnos bien porque podemos comer... ¿̇ellos tienen mejor educación? Si, y por eso les va mejor y tienen mejores oportunidades. A nosotros nos dan una educación para que seamos siempre pobres e ignorantes, pero la pregunta fundamental es ¿podemos hacer un cambio? ¿Podemos dejar de ser los pobres del sistema?, ¿podemos exigir una educación que sea equitativa para todos?... La realidad de un joven colombiano es una algunas veces difíciles porque tenemos que ser casi obligados a cumplir con ciertas cosas de las cuales no estamos de acuerdo, pero que sabemos que debemos hacerlas. Es complicado, porque todos deberíamos participar en esa toma de decisiones pero pues a veces ni nosotros mismos participamos, por ejemplo hay protestas que nos ayudan a todos pero no vamos o si vamos es para hacer cosas violentas y así no nos ponen cuidado. 


\section{Apéndice 2}

\section{Mi Realidad, tu realidad, nuestra realidad}

\section{Valentina Álvarez Moncada y Camila García Gómez*}

La realidad es la verdad que cada persona experimenta en su diario vivir, en el entorno en el que nos movemos y todo aquello que hacemos en nuestras vidas. La realidad de un joven aquí como yo, es estudiar; cumplir con nuestros compromisos diarios; tener el miedo a salir con el celular u otro objeto por riesgo a ser robado; es tener que trabajar porque sus padres no pueden satisfacer todas sus necesidades o simplemente porque los padres quieren que sus hijos los apoyen y ayuden en el trabajo que tienen siendo en algunos casos obligados a hacer esto; es estar más pendiente de la tecnología que de la propia naturaleza que nos brinda todo; es preferir chatear con los amigos y familiares que conversar cara a cara porque es más fácil; así mismo es apreciar la soledad, a preferir conectarse con ellos mismos; es valorar más a un equipo de futbol que a su propia familia y es preferir que no hagan las cosas a que nos enseñen como y hacerlo nosotros mismos.

Para muchos de los jóvenes Latinoamericanos su realidad se basa en no tener acceso a la educación por causa de escasos recursos o vivir en zonas donde una sede les queda muy lejos, debido a esto a estos jóvenes les toca trabajar en condiciones poco dignas haciendo mano de obra barata o simplemente acudir a robar para poder subsistir. Por lo contrario, para otros jóvenes latinoamericanos su realidad se basa en vivir en mejores condiciones y recursos accediendo a una buena educación básica, media y superior, tener carro a una edad temprana y poder satisfacer cada necesidad u ocio que se les pueda ocurrir.

La diferencia entre la realidad de un joven Europeo y uno Latinoamericano es que al Europeo se le brindan mayores oportunidades para satisfacer sus deseos y reproches que tenga, la educación que ellos reciben es más completa, tienen un mayor acceso económico a una universidad y la vida de ellos es más tranquila con respecto al tema de seguridad ya que donde viven es más seguro; en cambio al joven Latinoamericano le toca luchar más para poder obtener lo que quiera, no se le brindan tantas oportunidades en su educación y a nivel en general, y está más prevenido o asustado con respecto a la seguridad del entorno en el que se mueve. Ser Latinoamericano conlleva a saber que vivimos en un territorio lleno de tradiciones, culturas y riquezas; es comprender la diversidad de culturas que nos han permitido desarrollarnos como realmente somos; ser Latino es ser único; es sentirse en casa ya sea que estemos en cualquier parte desde México hasta la Patagonia; es aprender a amar todo nuestro territorio; Es reírse sabroso y con ganas; es tener remedio caseros para todo; es amar la comida hecha en casa; es saber que a pesar de tanta corrupción, masacres, sangre derramada por defender lo nuestro y ser tan criticados por el resto de países del mundo somos personas creativas, trabajadoras, soñadoras que poseemos una gran variedad de plantas y animales y que la mayoría de nuestros cultivos y agua dependen de muchos lugares del mundo. 


\section{Apéndice 3}

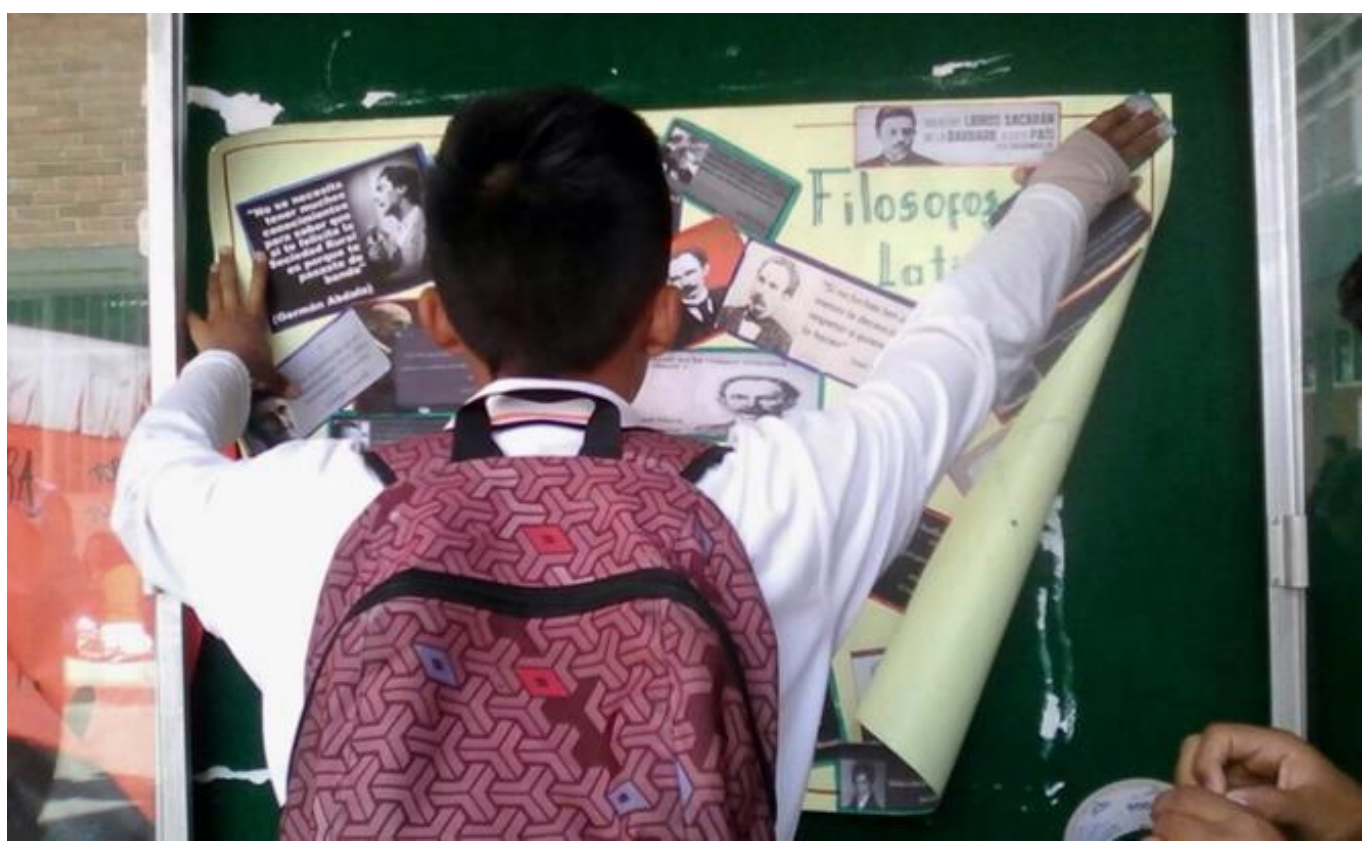

Fotografía de Semillero de Investigación INTUS LEGERE (Marzo 2016).

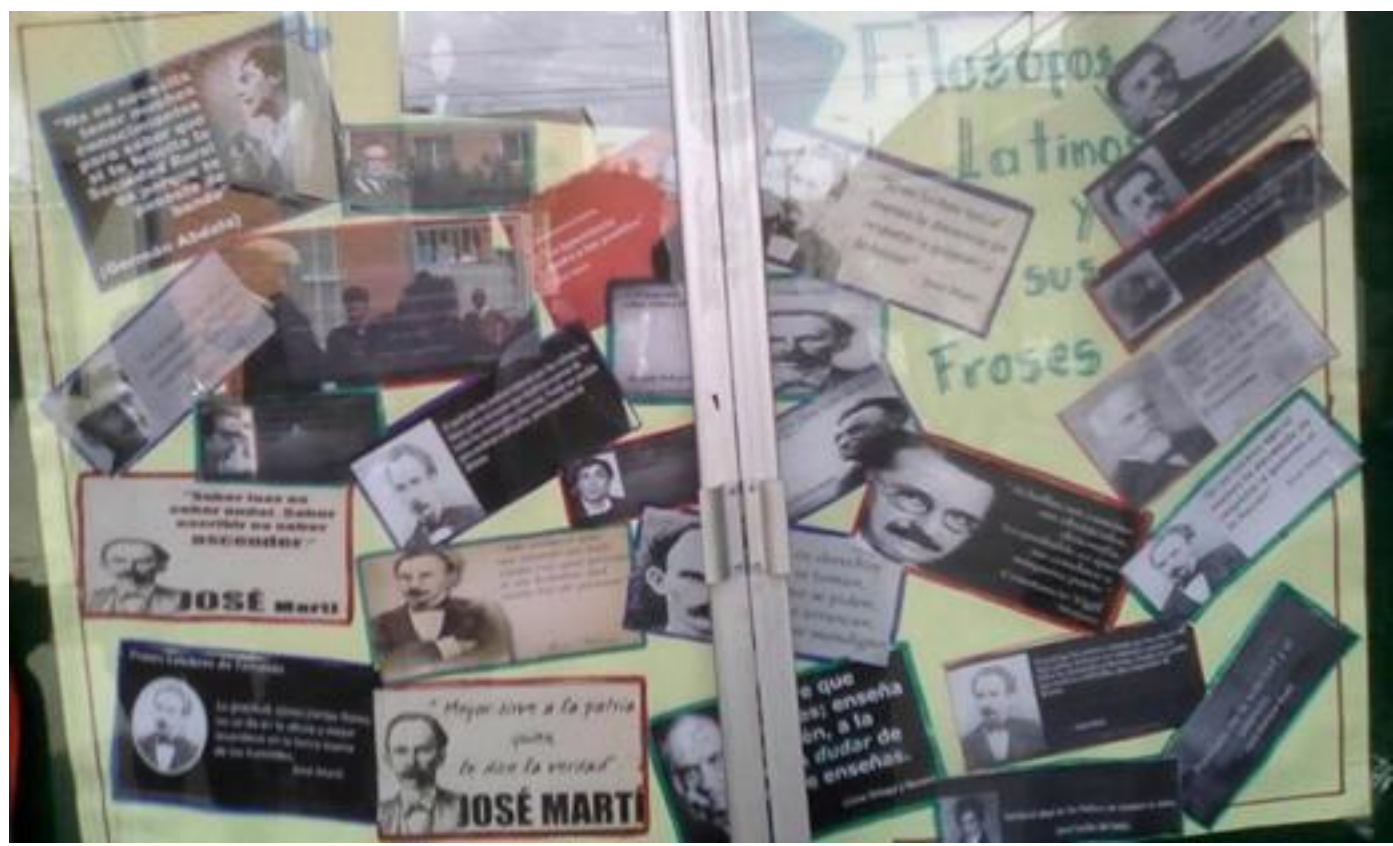

Fotografía de Semillero de Investigación INTUS LEGERE (Agosto 2016) 
Apéndice 4
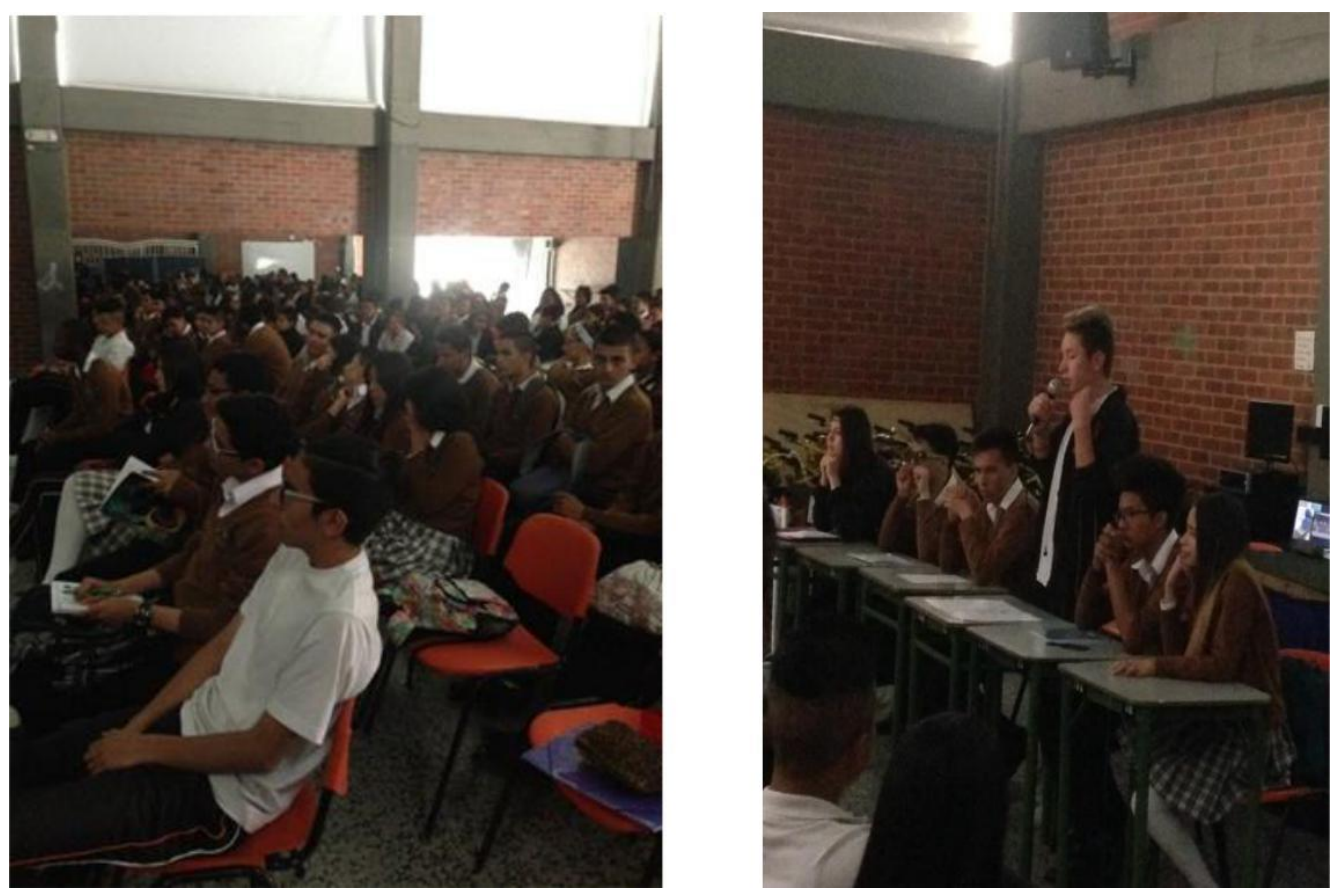

Fotografía del Semillero Intus Legere. Marzo 2017. Encuentro de Experiencias. Colegio CODEMA.

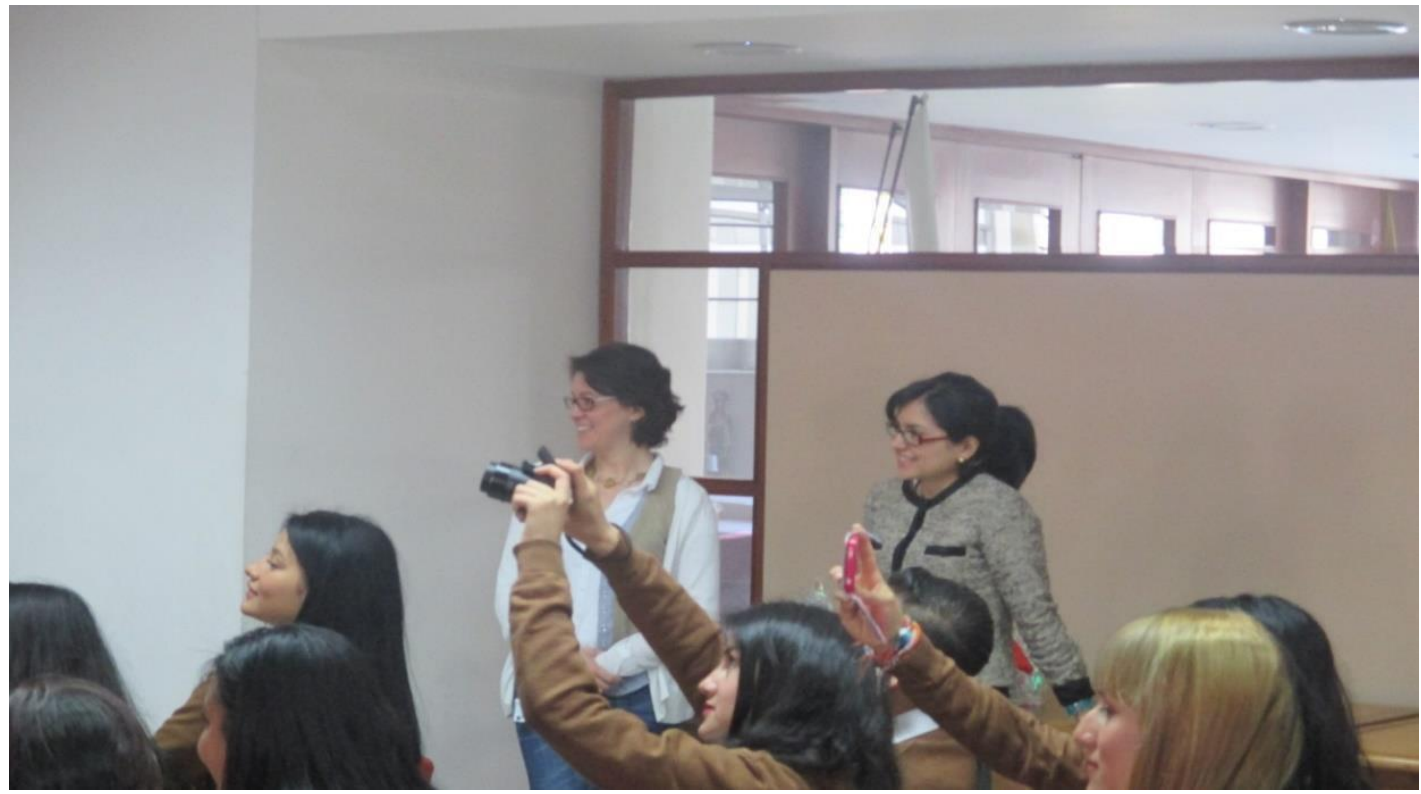

Fotografía Semillero Intus Legere. Encuentro Universidad Santo Tomás (Septiembre 2015). 


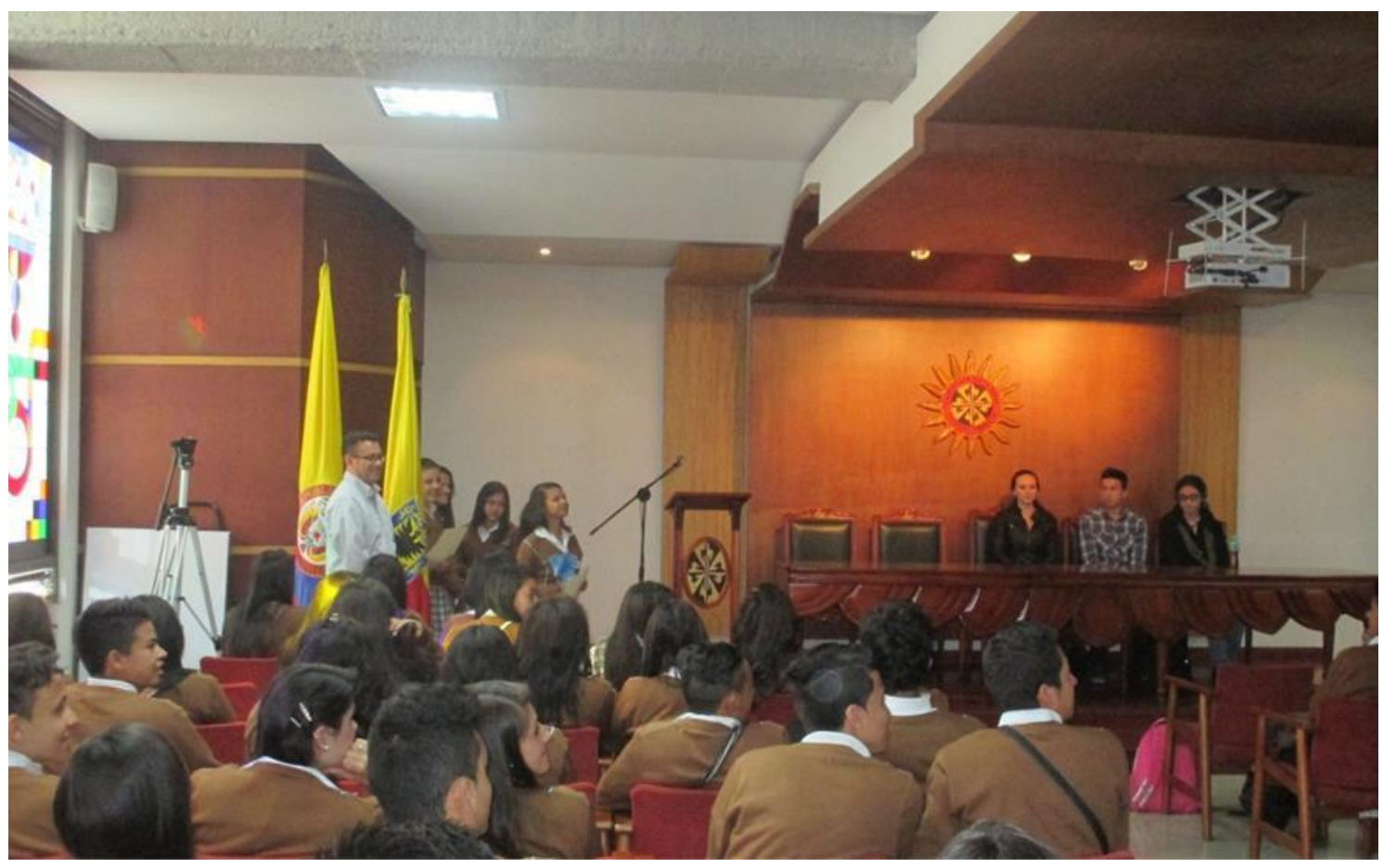

Fotografía Semillero Intus Legere. Encuentro Universidad Santo Tomás (Septiembre 2015). 
